\title{
Foot Traffic Effects on Grassland Soil Properties at the U.S. Air Force Academy, Colorado
}

\author{
Randy C. A. Whitecotton, Mark B. David, Robert G. Darmody, and David L. Price
}

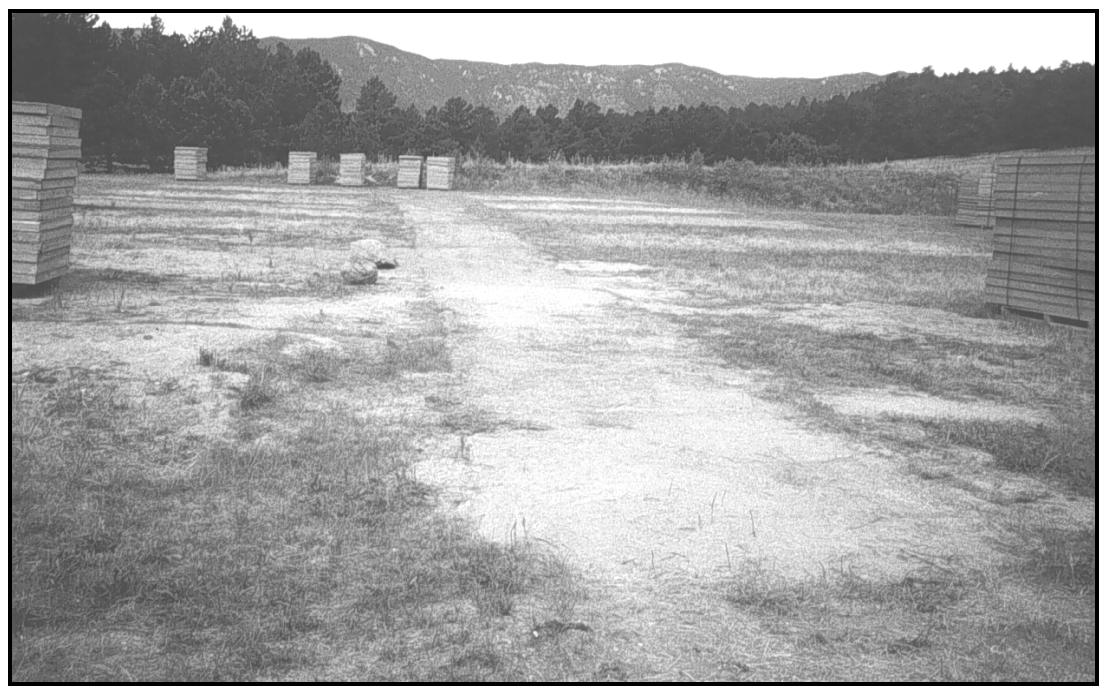

Soils and vegetation are subjected to stress and disturbance under human foot traffic. This study was conducted to determine whether training at the U.S. Air Force Academy adversely impacted soils and vegetation. In the summer of 1998, the effects of training on bulk density, infiltration, soil water holding capacity, soil total $\mathrm{C}$ and $\mathrm{N}$ concentrations, soil $\mathrm{C}: \mathrm{N}$ ratio, total aboveground biomass, and litter layer were comparatively studied at the Academy's Jack's Valley Training Area.

In May-June 1998 after 2 years of intensive training use, mean bulk densities of the top $6 \mathrm{~cm}$ of soil in the high use site $\left(1.37 \mathrm{~g} \mathrm{~cm}^{-3}\right)$ and moderate use site $\left(1.30 \mathrm{~g} \mathrm{~cm}^{-3}\right)$ were significantly different from bulk density of the reference site $\left(1.04 \mathrm{~g} \mathrm{~cm}^{-3}\right)$. Descriptive comparisons of the total aboveground biomass and litter showed a 68 percent decrease in total aboveground biomass and 91 percent decrease in litter when the high use site was compared to the low use site. Therefore, training use appears to adversely affect bulk density, infiltration, total aboveground biomass, and litter. Without restoration, previous research indicates that sites with increased bulk densities, decreased infiltration, and decreased total aboveground biomass and litter would be subject to increased soil erosion. 


\section{Foreword}

This study was conducted for the Office of the Directorate of Environmental Programs (DAIM), Assistant Chief of Staff (Installation Management) under Project 4A162720A896, "Environmental Quality Technology"; Work Units EN-TK7, "Land-Based Natural Resources Carrying Capacity" and EN-TM8, "Training Characterization \& Terrain Use Analysis for Training Land Carrying Capacity Analysis." The technical monitor was Dr. Victor Diersing, DAIM-ED-N.

The work was performed by the Ecological Processes Branch ( $\mathrm{CN}-\mathrm{N})$ of the Installations Division (CN), U.S. Army Construction Engineering Research Laboratory (CERL). The work was supported and partially funded by the University of Illinois at Urbana-Champaign (UIUC), the U.S. Air Force Academy at Colorado Springs, CO; the Air Force Institute of Technology (AFIT), Civil Engineer and Services School, at Wright-Patterson Air Force Base, Dayton, $\mathrm{OH}$; and Shepherd Miller Incorporated at Fort Collins, CO. This report contains a thesis submitted in partial fulfillment of the requirements for the degree of Master of Science in Natural Resources and Environmental Sciences in the graduate college of UIUC, 1999. Captain Randy Whitecotton is with AFIT. Dr. Mark David and Dr. Robert Darmody are with the UIUC Dept. of Natural Resources and Environmental Sciences. The CERL Principal Investigators were Dr. David L. Price and Patrick Guertin. Stephen E. Hodapp is Branch Chief, CN-N. Dr. J ohn T. Bandy is Division Chief, CN. The technical editor was Linda L. Wheatley, Information Technol ogy Laboratory.

The Director of CERL is Dr. Michael J . O'Connor.

\section{DISCLAIMER}

The contents of this report are not to be used for advertising, publication, or promotional purposes. Citation of trade names does not constitute an official endorsement or approval of the use of such commercial products. All product names and trademarks cited are the property of their respective owners.

The findings of this report are not to be construed as an official Department of the Army position unless so designated by other authorized documents.

DESTROY THIS REPORT WHEN IT IS NO LONGER NEEDED. DO NOT RETURN IT TO THE ORIGINATOR. 


\section{Acknowledgements}

The principal author Captain Randy Whitecotton wishes to express his sincere appreciation to Dr. Mark B. David, UIUC, for his extensive support and guidance during the proposal, analysis, and preparation of this thesis. He also wishes to thank the members of his graduate research committee: Dr. David Price, CERL, for assistance with the research proposal, for providing financial support, and for field assistance; Dr. Robert Darmody, UIUC, for assistance in the field and in the laboratory; and, Dr. Terry McClendon, Shepherd Miller Incorporated, for his financial and overall support of this research effort within the context of his work with the U.S. Air Force Academy.

The author also wishes to express his appreciation to J osh Kellar, Gene Gallogly, and SSgt J ohn Ingersoll, all Academy staff members, for providing such a com-

prehensive understanding of the research area training usage and history. He also wishes to thank: Dr. Harold Balbach, CERL, for his guidance in research project selection; A1C William Lonergan of the 10th Civil Engineer Group Welding Shop for expertly repairing a soil probe in less than 12 hours; Dr. Daniel Schneider, UIUC, for his assistance with the Universal Soil Loss Equation; Doug Cryer and Amy Sidner, EI Paso County NRCS Field Office, for their insight on the local soils; Karen Starks, Scott Wiesbrook, and J im Lang, all of whom are research professionals at UIUC, for their technical assistance in the laboratory; J ill Richards, Shepherd Miller Inc., for conducting the carbon and nitrogen analysis at Colorado State University and for coordinating the plant biomass and litter data; Lowell Gentry, research professional at UIUC, for his insight into thesis writing; Dr. J eff Dawson, UIUC, for his constructive proofreading and technical comments; Randy Rasmussen, ENSR Consulting and Engineering, and J ack Lowry, The Engineering Company, for providing maps and drawings; Dr. Susan Aref of the UIUC Statistical Consulting Lab for her assistance in statistical analysis; Suzanna Walaszek, Bill J ackson, Lisa Duwall, and Dan LaPine of CERL, Michael Gallegos and Airman Chris Smith of the 377th Civil Engineer Group, for providing drafting support; and Pat Guertin, CERL, for financial support.

The Air Force Institute of Technology, Civil Engineer and Services School funded the author's graduate education and CERL funded all of the travel and fieldrelated expenses. Without such financial support, this research effort would not 
have been possible. These organizations provided invaluable support at different times during the research project: 10th Civil Engineer Group, U.S. Air Force Academy, CO; 377th Civil Engineer Group, Kirtland Air Force Base, NM; Colorado State University Soil Testing Laboratory; Shepherd Miller, Inc.; U.S. Department of Agriculture--Agricultural Research Service, J ornada Range and Experimental Station; and the Natural Resources Conservation Service, EI Paso County, CO. 


\section{Contents}

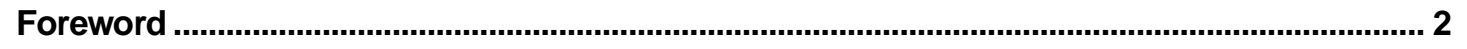

Acknowledgements............................................................................................................................. 3

List of Figures ..................................................................................................................... 7

$1 \quad$ Introduction ...................................................................................................................... 9

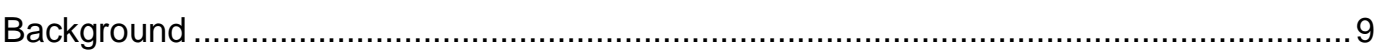

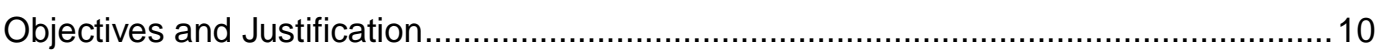

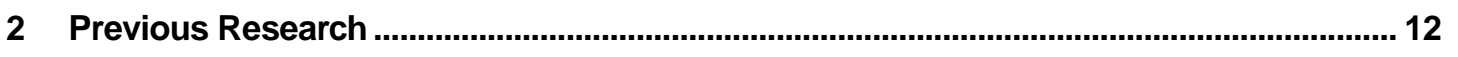

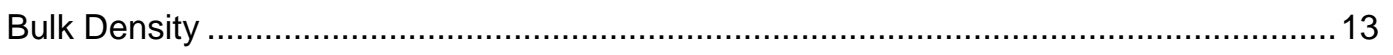

Infiltration and Pore Space .......................................................................... 13

Texture, Organic Matter, and Soil Moisture ............................................................ 14

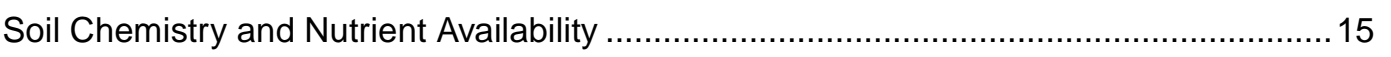

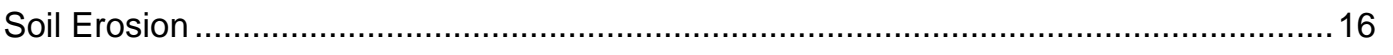

Vegetative Patterns ..................................................................................... 17

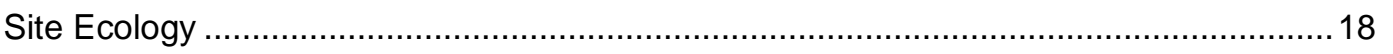

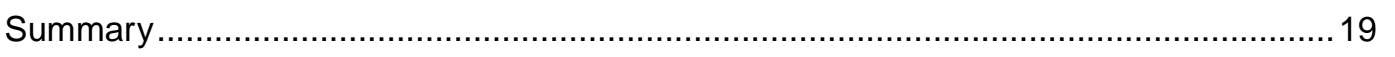

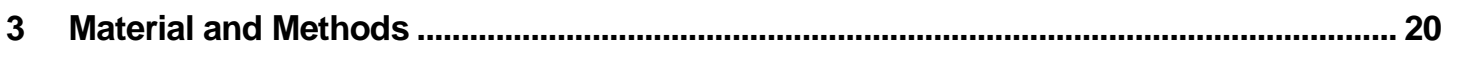

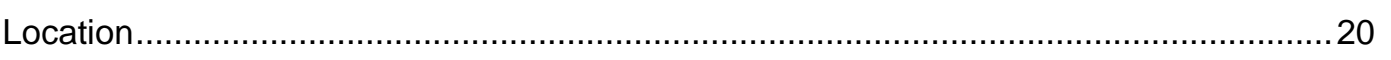

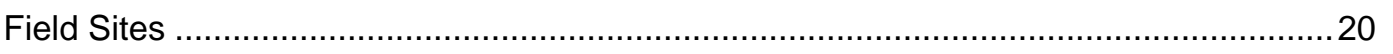

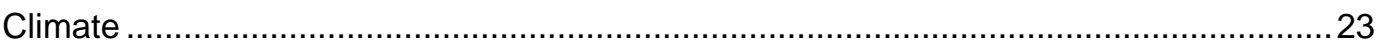

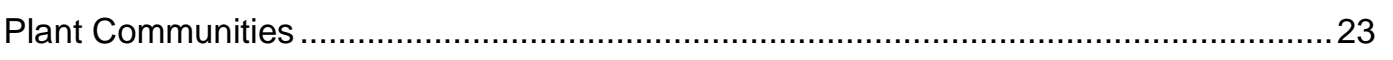

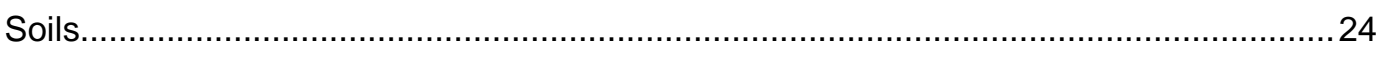

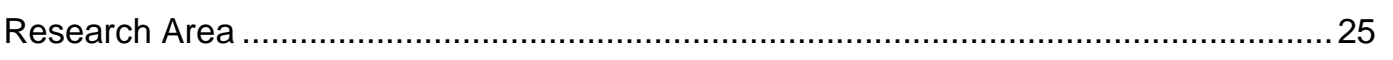

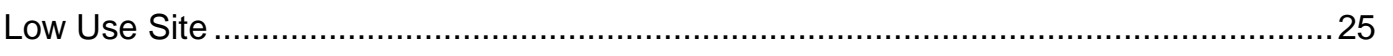

Moderate Use Site ..................................................................................25

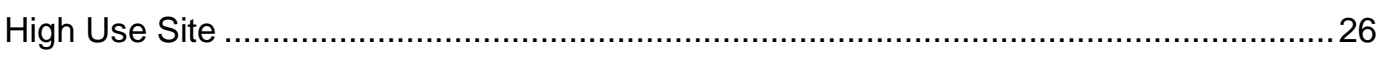

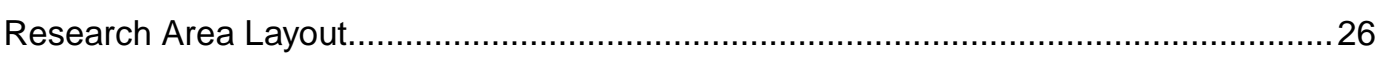

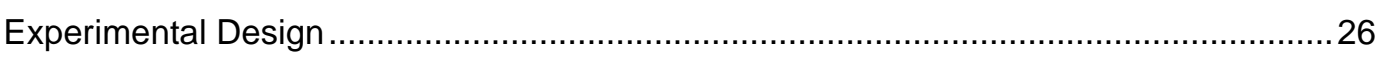

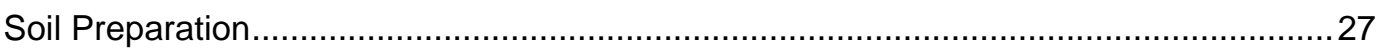

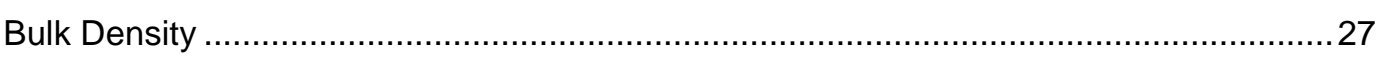

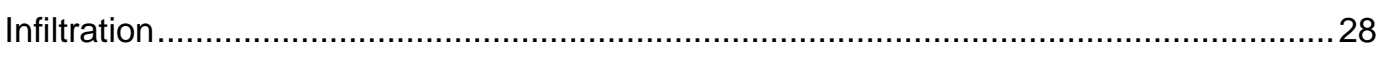

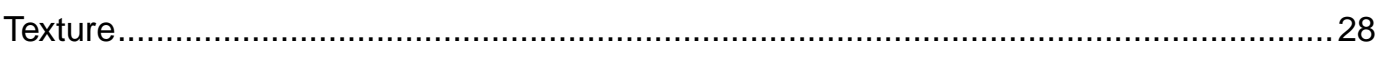




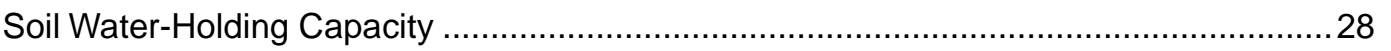

Soil Total Carbon and Nitrogen Analysis ..........................................................29

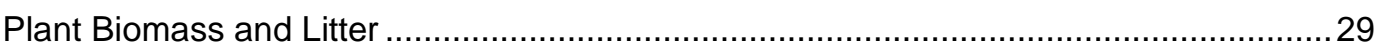

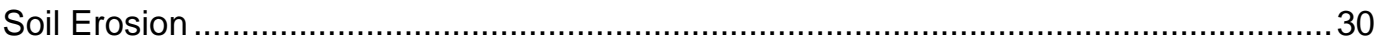

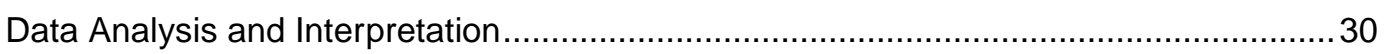

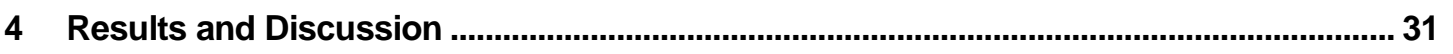

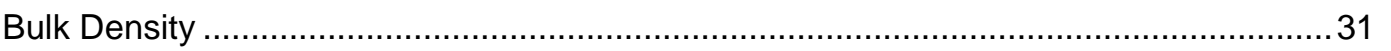

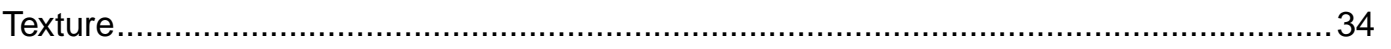

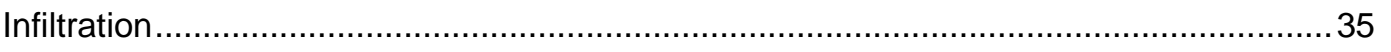

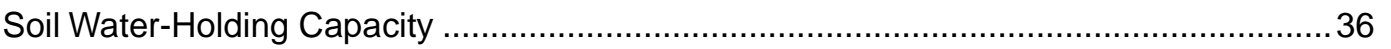

Soil Total Carbon and Nitrogen Analysis .......................................................... 38

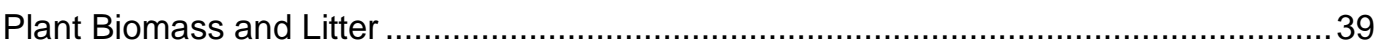

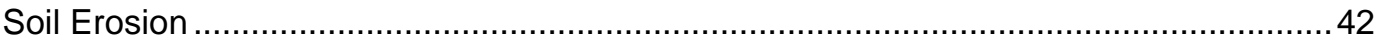

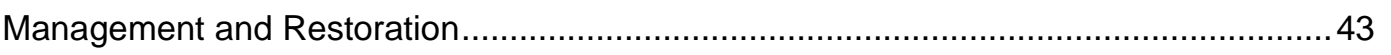

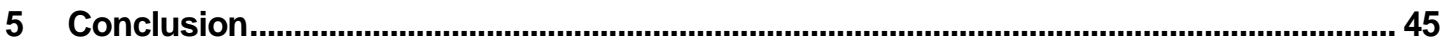

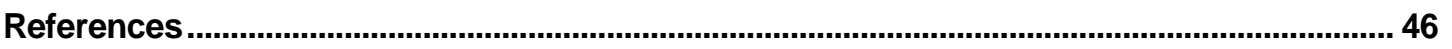

Appendix A: $\quad$ Bulk Density and Coarse Fragment Data ................................................................. 51

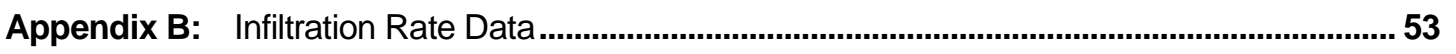

Appendix C: Particle Size Analysis Results....................................................................................... 54

Appendix D: Soil Water Holding Capacity Data .................................................................... 57

Appendix E: $\quad$ Total Carbon and Nitrogen Concentration Analysis Results................................... 58

Appendix F: $\quad$ Total Aboveground Biomass and Litter Results........................................................59

Appendix G: Universal Soil Loss Equation Data ............................................................................... 62

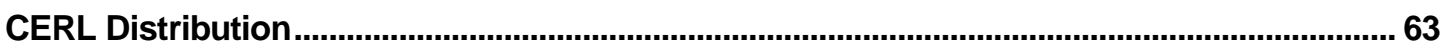

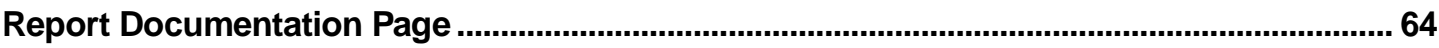




\section{List of Figures}

1 Map of the central Colorado region showing the U.S. Air Force Academy north bf the City of Colorado Springs.

Map of the U.S. Air Force Academy showing Jack's Valley Training Area at the Academy's northern boundary (shaded) . ..........................................................22

3 Map of the Research Area at Jack's Valley Training Area - three study sites are labeled as low use (reference), moderate use, and high use. The five subsamples within each site are numbered.

$4 \quad$ Pre- and post-encampment mean soil bulk densities and adjusted soil bulk densities (with standard errors, $n=25$, and adjusted for coarse fragments) for grassland soils at the USAFA JVTA based on intensity of use. Means with same letter and case style are not significantly different ( $p>0.05)$.

5 Map of soil surface textures across the grassland soil research area at the USAFA's JVTA based on particle size analysis results.

6 Mean infiltration rates (with standard errors) for grassland soils at the USAFA JVTA based on intensity of use; means with the same letter are not significantly different $(\mathrm{p}>0.05)$.....

$7 \quad$ Moisture retention curves (with standard errors) for grassland soils $(0-5 \mathrm{~cm})$ at the USAFA JVTA based on intensity of use. Pressure was applied at three different pressures 0.10 bars, 0.33 bars (field capacity), and 15 bars (permanent wilting point). .......................................................................................... 37

8 Simple linear regression of total carbon concentration to total nitrogen concentration (with $r^{2}$ value, $n=75$ ) for grassland soils at the USAFA's JVTA.

9 Mean total carbon concentration, total nitrogen concentration, and ratio of total carbon to total nitrogen concentration (with standard errors) for grassland soils at USAFA's JVTA based on intensity of use. Means within a depth and with same letter are not significantly different $(p<0.05)$

10 Comparison of total aboveground biomass and litter for grassland soils at USAFA's JVTA based on intensity of use (high use site divided into two plots: a plot in the center of basic cadet training encampment area and a plot at the edge of encampment area).

11 Comparison of Universal Soil Loss Equation modeled soil loss rates for grassland soils at the USAFA's JVTA based on intensity of use (high use site divided into two plots: a plot in the center of basic cadet training encampment area and a plot at the edge of encampment area). 



\title{
1 Introduction
}

\section{Background}

The mission of the U.S. Air Force is one of national defense. To accomplish this vital mission, the Air Force must produce qualified officers to lead the Air Force in protecting the nation. The U.S. Air Force Academy (USAFA) is one of the Air Force's three primary sources for producing qualified officers. Due to the military nature of its mission, the Academy must conduct training exercises in natural areas in order to prepare its cadets for future war and peacetime contingency operations. In carrying out its mission to produce qualified officers, the Academy uses the vast natural resources present in the Colorado Springs, CO, area for training the cadets in orienteering, physical fitness, combat arms, and survival. This use, though vital to the mission of producing qualified Air Force officers, produces some negative consequences on the natural resources of the area.

In recent years the Department of Defense (DoD) has become more concerned with the natural resources entrusted to it on its 10.1 million hectares of land. As the third largest Federal land management agency, the DoD plays a very important role in natural resources management. Sherri W. Goodman, Deputy Under Secretary of Defense for Environmental Security, stated:

\begin{abstract}
Sustaining our Nation's military training and testing lands through ecosystem management is among the most important DoD environmental goals. As a critical element of ecosystem management, biodiversity conservation contributes directly to military readiness. Biodiversity helps us achieve military readiness in harmony with nature.
\end{abstract}

The training activities undertaken at the USAFA, if not properly managed, may ultimately lead to degraded plant and animal habitats and diminished water quality in watersheds of the area. This research project, therefore, was designed to complement a larger, proactive USAFA-funded research effort to develop a natural resource management tool for all of the Academy's ecosystems. Included within this research project was an analysis of the impacts from cadet and other training activities (Army, Air Force Reserve, Air National Guard, Reserve Officer Training Corps cadets, Boy Scouts of America, and Federal, state, and local law enforcement agencies). 
Soil, as one of these natural resources, can be disturbed by mechanical means (e.g., heavy equipment), livestock and animal trampling, and human recreational use. It is hypothesized that the training activities undertaken at the USAFA J ack's Valley Training Area (J VTA) lead to soil and vegetative disturbances most similar to the impacts caused by human recreational use. Thus, these potential consequences were studied using many of the methods predominantly employed in recreational use impact assessment.

\section{Objectives and Justification}

The objectives of this research study were to:

1. determine the effects of foot traffic from cadet and other training uses on grassland vegetative, soil physical, and soil chemical properties

2. use these measured soil and vegetative properties to assess the potential for soil erosion.

In their Statement of Work, McClendon and Childress (1997) wrote that the USAFA J VTA is used extensively for mission-essential cadet training activities. Although these training activities are necessary for leadership development, it is important to recognize that good land stewardship is considered a crucial component of the Academy's overall mission. "An important aspect of good land stewardship is the determination of proper land use, i.e., the level of use that can be sustained by an area without inducing a downward trend in ecological condition." This level is often termed the "carrying capacity" of the area (McClendon and Childress 1997; Price et al. 1997).

The Ecological Dynamics Simulation (EDYS) Model is being developed with support from the U.S. Army, the National Park Service, the Natural Resources Conservation Service, and the Agricultural Research Service. The EDYS Model is a land management tool for investigating ecological responses to a combination of anthropic and natural factors or disturbances. Application of the EDYS Model at the J VTA will determine its ecological carrying capacity (McClendon and Childress 1997). 
The EDYS Model is actually a system composed of three separate models: an ecosystem dynamics model (the Community Model), a Spatial Model, and a Management Model. Childress et al. (1999) stated:

This system is designed to characterize objectives for a proposed training activity, estimate training and maintenance costs, evaluate effects of the activity on current land use and environmental management practices, estimate ecological and environmental effects of the proposed activity for each of the alternative areas, and evaluate remediation and restoration activities appropriate for each area.

The Community Model is composed of six modules: Climate, Soils, Plant Growth, Community Structure, Animal, and Disturbance (Childress et al. 1999). This research project studied the impacts of human trampling at JVTA by drawing on years of recreation impact analysis research. Results of the human trampling research will contribute vital information to the Soils and Disturbance modules of the EDYS model. In combination with the trampling impact data on the grassland soils research area and the J VTA field data collected by Dr. Terry McClendon's research team, the EDYS model will be used to estimate the carrying capacity of JVTA. Armed with this tool, USAFA environmental management personnel will be better prepared in their ongoing, proactive effort to make sound land management decisions. 


\section{Previous Research}

Past research on human foot traffic disturbance (trampling) of soil has focused primarily on recreational sites (e.g., campgrounds, trails, and picnic areas). Earlier studies found that foot traffic has not only caused direct compaction of the soil, but it has also led to many other significant impacts. Compaction by foot traffic has been shown to increase root exposure and soil erosion, as well as to decrease the infiltration rate, root penetration and growth, soil moisture content, thickness of surface A horizons, depth of litter layer, and vegetative cover (Settergen and Cole 1970; Dunn et al. 1980). Impacts of recreational activities on soils, as will be discussed throughout this thesis research, are generally concentrated in the litter layer and surface A horizon.

Dunn (1984) stated that studies on recreational impacts are usually conducted using one of three methods: (1) comparative, (2) longitudinal, and (3) simulation. Comparative studies are the most frequently employed of the three methods to assess recreational impacts. This comparative research method uses undisturbed natural sites as control sites and adjacent recreational sites as test sites. The recreational site impacts are then assessed by comparing the differences between the measurements collected on the control site to the measurements made on the adjacent test sites. The longitudinal research method usually employs a series of permanent sites located across a recreational area to measure the longterm impacts of recreation. The simulation method typically employs mechanical devices to simulate the impacts caused by recreation.

Compaction is the most widely recognized impact resulting from recreational use. Studies have found that recreational sites were most heavily compacted and void of vegetation in the center of the activity area (Cole 1982). This compaction decreased as the distance from the center increased. Dale and Weaver (1974) and Dawson et al. (1974) reported that studies on trails indicated compaction was prevalent in the trail treads. This compaction impact diminished with an increase in distance from the trail center (Ward and Berg 1973; Dawson et al. 1974).

Dunn (1984) reported that compaction can be assessed by using four measurements: (1) bulk density, the mass per unit volume, (2) penetrability, the resistance to penetration, (3) infiltration, the absorption of water per unit time, and 
(4) soil moisture content, the amount of water occupying the soil pore space. Bulk density and infiltration will be discussed further.

\section{Bulk Density}

Human foot traffic or trampling has been shown to increase bulk densities on recreation sites (Settergen and Cole 1970; Trumbull et al. 1994). Monti and Mackintosh (1979) found severe compaction and high bulk densities on camping sites when compared to the control site. In comparing the bulk densities between the camping sites and the control site, they found a 34 percent increase in bulk densities over those of the control site. Dotzenko et al. (1967) found in a study of Rocky Mountain National Park campsites an increase ranging from 30 to 55 precent in bulk densities of the high use sites compared to those of the low use sites. Foth (1990) stated that this large increase in bulk densities due to camping activities was comparable to the compaction caused by tractors and heavy equipment.

In a study of the impacts of military camping on silt loam soils in the Ozark Mountains of Fort Leonard Wood, Missouri, Trumbull et al. (1994) compared high use, low use, and no use (control site) camping sites. They found that bulk densities were significantly lower on the control site in comparison to the low use and high use sites, but there was no significant difference in bulk densities between the low use and high use sites.

\section{Infiltration and Pore Space}

Infiltration is a measure of a recreational site's compaction. Trumbull et al. (1994) found that infiltration rates significantly decreased on recreational sites. Recreational use removed the litter layer, vegetative cover, and surface A horizon (Monti and Mackintosh 1979; Dunn et al. 1980). The loss of the litter layer and vegetative cover, compaction, and subsequent erosion of the surface A horizon reduced water infiltration (Lutz 1945; Brown et al. 1977; Ritter et al. 1995). Dunne and Leopold (1996) stated the decrease in vegetation due to changes in land use caused large differences in infiltration on similar soil types. Corresponding to the increased compaction present on the recreationally disturbed sites, Monti and Mackintosh (1979) found infiltration rates decreased 20 to 30 times over the infiltration rates on the control sites. Research on compacted, sandy loam and loamy sand soil plots in England showed a significant reduction in infiltration rates during heavy rains (Reed 1983). Lutz (1945) reported from his studies in Connecticut state parks that recreational trampling reduced 
permeability of the upper $10 \mathrm{~cm}$ of soil by 6 times on sandy soils and 20 times on sandy loam soils when compared to the control sites. Recreational trampling reduced moisture in A horizons (0-30 cm depth) of both coarse and fine-textured soils (Settergen and Cole 1970). In clay soils, evaporation of ponded water led to the development of crusts that further reduced infiltration (Le Bissonnais and Arrouays 1997).

On wet sites, trampling also reduced pore space and the availability of moisture (Dunn et al. 1980). In a study of marching impacts at the U.S. Military Academy, Geohring et al. (1992) found that marching traffic on wet soils caused compaction of the soils. Compaction affected pore space directly by reducing the macropores, which in turn restricted air and water movement into the soil. For example, studies of the top $8 \mathrm{~cm}$ of I owa campground soils indicated soil macropore space was 18 percent lower on campsites than on the control sites (Dawson et al. 1978).

Dunn et al. (1980) reported from a South Carolina study that trampling compressed the soil pore space, which restricted water and air movement. Compaction decreased the soil water holding capacity of Piedmont sandy loam soil campsites. Conversely, on South Carolina Sandhill and Coastal Region soils with many large macropores, compaction actually reduced the large macropores, which resulted in a higher soil water holding capacity on these campsites (Dunn et al. 1980).

As compaction increased, this reduction in aeration became a prime reason for the restriction of root el ongation. Reduction of pore space al so created a shortage of oxygen that can restrict the flow and diffusion of dissolved nutrients. Restriction of the flow and diffusion ultimately led to a difficulty in plant uptake of these dissolved nutrients (Dunn et al. 1980).

\section{Texture, Organic Matter, and Soil Moisture}

The texture, organic matter content, exposure to rainfall, and soil moisture content of the soil are indicators of a soil's susceptibility to compaction (Reed 1983). Coarse textured soils with low organic matter contents were more susceptible to compaction than high organic matter content soils with low initial bulk densities (Dunn 1984). Further, Dotzenko et al. (1967) found in their Rocky Mountain National Park study that coarse textured soils with low organic matter contents compacted more than soils with higher organic matter contents and lower densities, due mostly to the large macropores in coarse textured soils. Additional reasons cited for the greater compaction of coarse textured soils included differences 
in ground cover and litter layers (Dotzenko et al. 1967). Interestingly, Stewart and Cameron (1992) found that small amounts of stones in the soil reduced the compaction rate by dispersing the trampling pressure.

Stewart and Cameron (1992) showed that trampling did not compact organic soils, but they also found that organic soils were not ideal for use as trails because of their low strength and high water content. When high organic matter content soils were trampled, the soils structurally degraded and became especially prone to erosion. Dotzenko et al. (1967) showed recreational use decreased organic matter content on soils in Rocky Mountain National Park. They reported that, as organic matter content increased, the soil compaction decreased (Dotzenko et al. 1967). Trumbull et al. (1994) found a significant decrease between the control and high use recreational site in total organic carbon as well as an increase in the rock volume, which they attributed to the erosion of the upper soil horizons.

Soil moisture content was the primary indicator of a soil's susceptibility to compaction (Bayfield 1973). Studies concluded that mineral soils were prone to compaction when wet due to the corresponding decrease in soil strength (Stewart and Cameron 1992). Bayfield (1973) showed wet mineral soils in Scotland compacted more than dry organic topsoils. Studies by Dotzenko et al. (1967) showed soil moisture content decreased on sites compacted by recreational use. Dunn et al. (1980) cited the loss of litter layer and organic matter as contributing significantly to the decrease in the percent soil moisture of recreational sites.

\section{Soil Chemistry and Nutrient Availability}

Dunn et al. (1980) reported that soil compaction changed nutrient availability and reduced root penetration and soil aeration. The poor aeration due to trampling-induced compaction increased anaerobic microbial activity to such an extent that over-production of some essential micronutrients (e.g., iron and manganese) resulted in plant toxicity (Dunn et al. 1980). Studies by Young and Gilmore (1976) on Illinois campgrounds found recreational use caused increases in soil pH, nitrogen, phosphorous, potassium, calcium, and sodium concentrations. In plant communities, water and nitrogen $(\mathrm{N})$ are usually limited in availability. The availability of nitrogen and water are crucial to successional recovery patterns and rates (Childress et al. 1999). McClendon (1997) stated that during succession, total $\mathrm{N}$ concentration typically increased, whereas available N concentration typically decreased. LaPage (1962) concluded that compaction was most prevalent in the upper $15 \mathrm{~cm}$ of soil, and other researchers found 
that roots were nearly absent in these upper $15 \mathrm{~cm}$ of soil on recreational sites (Settergen and Cole 1970).

\section{Soil Erosion}

Sites that had low infiltration rates, reduced vegetation, and a minimal litter layer were susceptible to soil erosion (Monti and Mackintosh 1979; Trumbull et al. 1994). Settergen and Cole (1970) also found that recreational sites were subject to sheet erosion due to decreased vegetation and litter cover. Morgan (1995) defined soil erosion as involving two processes: particle detachment from the soil mass, and the movement of these detached soil particles by erosive agents (e.g., moving water and wind). On sites unaffected by recreation, erosive processes were diminished because detachment was reduced by: (1) vegetation intercepting raindrops before striking the surface, (2) the litter layer serving as a protective mat, and (3) roots binding together soil particles (Trumbull et al. 1994; Ritter et al. 1995).

The litter layer was crucial in determining a site's susceptibility to compaction and erosion (Trumbull et al. 1994) because the litter layer and the A horizon served to incorporate the organic matter and retain moisture (Dunn 1984). Further, the litter layer served as a protective mat by shielding against the negative impacts of human foot traffic. Dunn et al. (1980) reported trampling reduced vegetation and litter cover, leading to erosion, which further removed organic matter and soil of the A horizon. LaPage (1967) reported ground cover loss on silt loam soils was accelerated by human kicking of loose gravel. On sites used for camping, for example, Young (1978) determined from studies on Illinois campgrounds that the litter layer decreased by 71 percent and bare ground increased by 56 percent when compared to the control site. Trumbull et al. (1994) reported that recreational sites lost between 28 to $61 \mathrm{~cm}$ of soil due to erosion. Bare ground, or the lack of vegetation and ground cover, proved to be the foremost factor contributing to soil erosion (Hofmann and Ries 1991). Dunn et al. (1980) reported a significant decrease in the depth of the litter layer and A horizon of the recreational site when compared to the undisturbed control site. With the loss of litter layer and vegetative cover, finer soil particles were eroded by wind forces (Lutz, 1945). F urthermore, a decrease in organic matter content resulted in erosion, runoff, and crusting (Le Bissonnais and Arrouays 1997). 


\section{Vegetative Patterns}

Vegetation on recreational sites can be impacted when roots are exposed by erosion (Cole 1982). This exposure then impaired root function, thus creating a hostile environment for plant regeneration (Dunn et al. 1980). Dunn et al. also reported that, during the first year of recreational use, the rate of vegetative cover loss rapidly increased, but this rate of vegetative cover loss leveled off during subsequent years of recreational use. Dunn and Carroll (1985) found recreational use decreased vegetation and litter by 56 percent and the species composition by 25 percent in comparison to the control site.

Studies on campsites in Michigan found that trampling affected grasses less than broad-leaved species, and that ground cover survived better in partial shade due to the lack of sun to reduce ground moisture (Wagar 1964). Yorks et al. (1997) reported grasses were most resistant to recreational trampling, forbs suffered immediate losses following recreational use, and trees and shrubs decreased in long-term diversity following recreational trampling. They ranked the lifeforms from highest resistance to lowest resistance: grasses, trees, forbs, and then shrubs. Cole (1995a) reported that recreational sites with shrubs as the predominant vegetative type sustained more damage and took longer to recover than sites with forbs as the predominant vegetative type. Trees were the least affected by trampling (Lutz 1945; Brown et al. 1977; Cole 1982). Tree seedlings, however, were typically eliminated by trampling, which reduced the likelihood of natural reproduction replacing mature trees on recreational sites. Although tree height growth was not curtailed by trampling, diameter growth was reduced (LaPage 1962). Brown et al. (1977) reported, however, from studies on glacial till soils in Rhode Island, that both tree height and diameter decreased on recreational sites. Trumbull et al. (1994) found that, of the numerous impacts on vegetative growth, woody stem density was the most sensitive. They also concluded that canopy cover was practically indistinguishable between the control and impacted sites.

Cole (1995b) studied four mountainous regions across the United States and found that the shoe type as well as the weight of the trampler can adversely impact vegetative cover and height. He reported, though dependent on vegetation type, that lug-soled boots caused moderately more vegetative cover loss than running shoes. Even 1 year after the recreational trampling, the vegetative cover loss was still present, but the difference in vegetative cover loss due to shoe type was no longer evident. This impact from shoe type affected vegetative cover loss more than vegetative height. Moreover, Cole also found that, with low trampling intensities (i.e., number of passes across a recreational site), heavy tramplers caused more vegetative loss than light tramplers did. Regardless of 
vegetation type, the heavier trampler also impacted the vegetative height more than the vegetative cover. This reduction of the vegetative height proved even more apparent 1 year after the recreational trampling than immediately following the trampling (Cole 1995b).

Recreational use does not uniformly denude vegetation across campsites. Dunn and Carroll (1985) found that the centers of campsites were most denuded of vegetation and litter. This vegetation only recovered outside of a 7-m radius from the center of the campsite. Cole (1995a) concluded from his research that overall damage to vegetation resulting from recreational use can be minimized by restricting the camping to a few sites rather than spreading it out across several sites.

\section{Site Ecology}

The ecosystems studied by Dunn et al. (1980) advanced through complex successional stages resulting from many interacting ecological processes. As these ecosystems were used for recreation, these ecological processes were modified. Therefore, recreational use has been considered a disturbance to the ecology of a site. White and Pickett (1985) defined disturbance as: “... any relatively discrete event in time that disrupts ecosystem, community, or population structure and changes resource or substrate availability or the physical environment."

Dunn et al. (1980) argued that successional ecology was affected by the clearing of vegetation during recreational site construction and that resulted in an earlier seral stage plant community. During construction of recreational sites, the re moval of trees and ground vegetation increased the amount of radiation and moisture, which reached the surface (Dunn 1984). In addition, the disturbance of the soil created conditions that allowed invaders to take hold. This new recreational use created by the construction had three effects: (1) trampling of vegetation through foot traffic and mechanical damage, (2) kicking up gravel or rocks, which can further damage vegetation, and (3) vandalism of trees. Together, these effects induced decay, disease, and increased competition among the plants on the site (Dunn 1984). Dawson et al. (1978) found in their lowa campground study that following a camping-induced disturbance, native vegetation was pushed out by trampletolerant plants or replaced altogether by bare ground. In addition, Dunn and Carroll (1985) stated that a rapid decline of ground cover occurred over the first year of recreational use. This rate of decline leveled off after a couple of years of use and more drought resistant species invaded the site. This reduced competition encouraged the growth of the invaders, changing the community composition of the recreational site. 


\section{Summary}

In conclusion, recreational impacts on soils, predominantly restricted to the litter layer and surface mineral horizon, have been studied over several decades employing three primary methods of analysis: comparative, longitudinal, and simulation. These previous studies across several different soil types indicated that compaction as well as numerous other consequences resulted directly from recreation. These other consequences included: increases in soil erosion and root exposure; decreases in soil moisture content, infiltration rate, soil water holding capacity, soil aeration, litter layer and surface horizon depth, organic matter content, root penetration and growth, and vegetative growth; changes in nutrient availability and the successional ecology of the recreational site. 


\section{Material and Methods}

\section{Location}

The research area was in the JVTA at the USAFA. ENSR (1997) reported that the Academy is bordered on the east by Monument Creek and Interstate 25, on the west by the Rampart Range in the Pike National Forest, on the south by Colorado Springs, and on the north by sparsely developed, but ever growing, unincorporated EI Paso County, Colorado (Figure 1). The USAFA totals 7500 ha, whereas J VTA includes approximately 900 ha, 12 percent of USAFA's total area. J ack's Valley is situated on the northern edge of USAFA (Figure 2). The elevation of J ack's Valley ranges from 2035 to $2200 \mathrm{~m}$, and the elevation of the research area ranges from 2040 and $2050 \mathrm{~m}$.

\section{Field Sites}

Three field sites were used in the JVTA research area sampling: a low use site (reference site), a moderate use site (test site), and a heavy use site (test site) (Figure 3). During the first visit to the Academy in mid-May 1998, the research area was selected based on whether a suitable reference site existed to which the training sites could be compared. This research project assessed the impacts of the cadet training activities on the high and moderate use test sites and compared the impacts to the low use reference site (an entirely undisturbed, control site with similar slope, soils, aspect, and elevation did not immediately exist in J VTA; therefore, this low use site was accepted as the reference site to which the two test sites could be compared). The reference site was outside of the main basic cadet training encampment area whereas the test sites were in this main training encampment area. The test sites and the reference site were similar to each other in terms of vegetation, soils, slope, and aspect (the aspects of the test sites differed from the aspect of the reference site, but due to the minimal grade of the slopes ( $<2$ percent) the differing aspect factor was not thought to have any effect). This allowed for the comparison of the effects of cadet and other training disturbance on the soil and vegetative properties. 


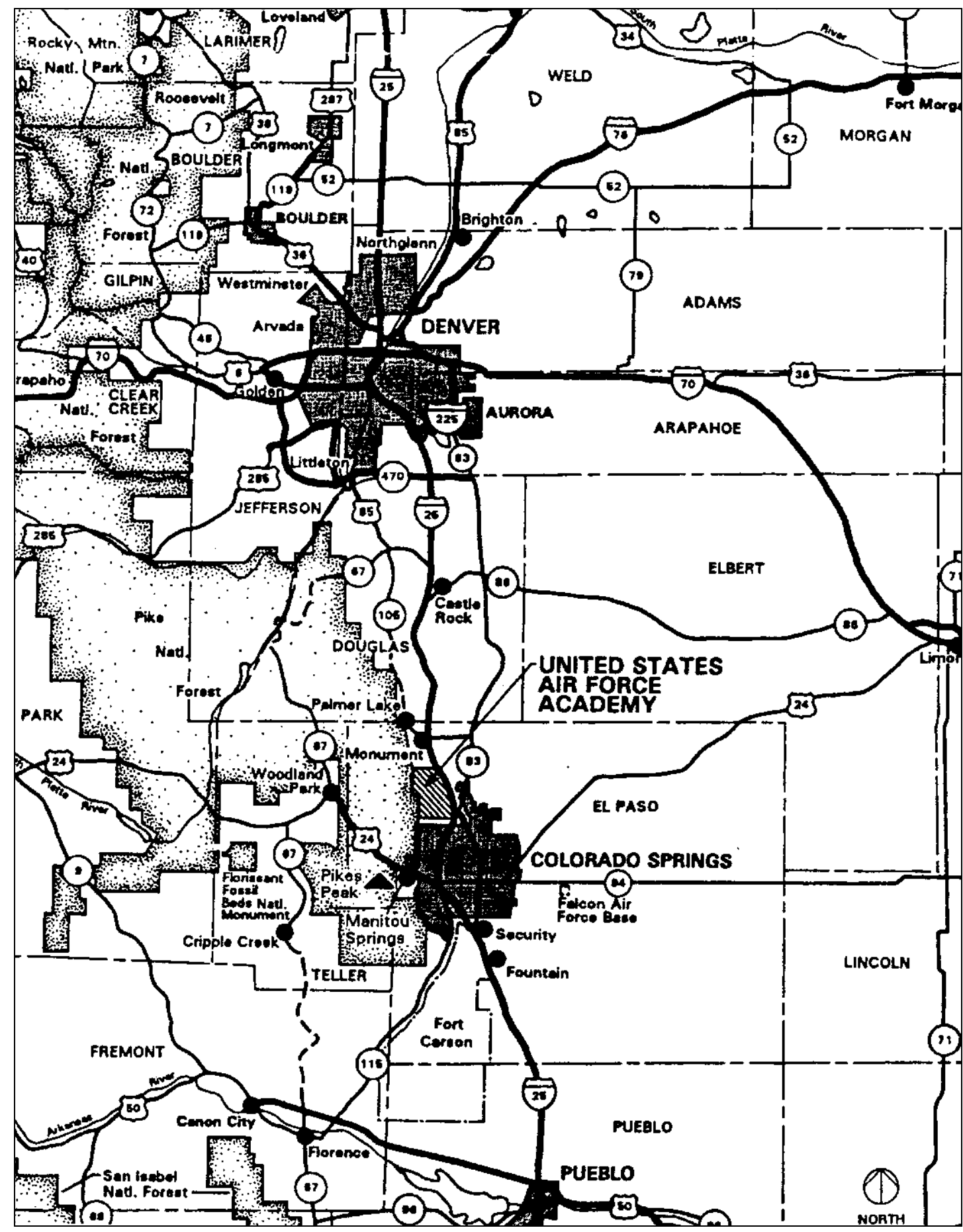

Figure 1. Map of the central Colorado region showing the U.S. Air Force Academy north of the City of Colorado Springs. 


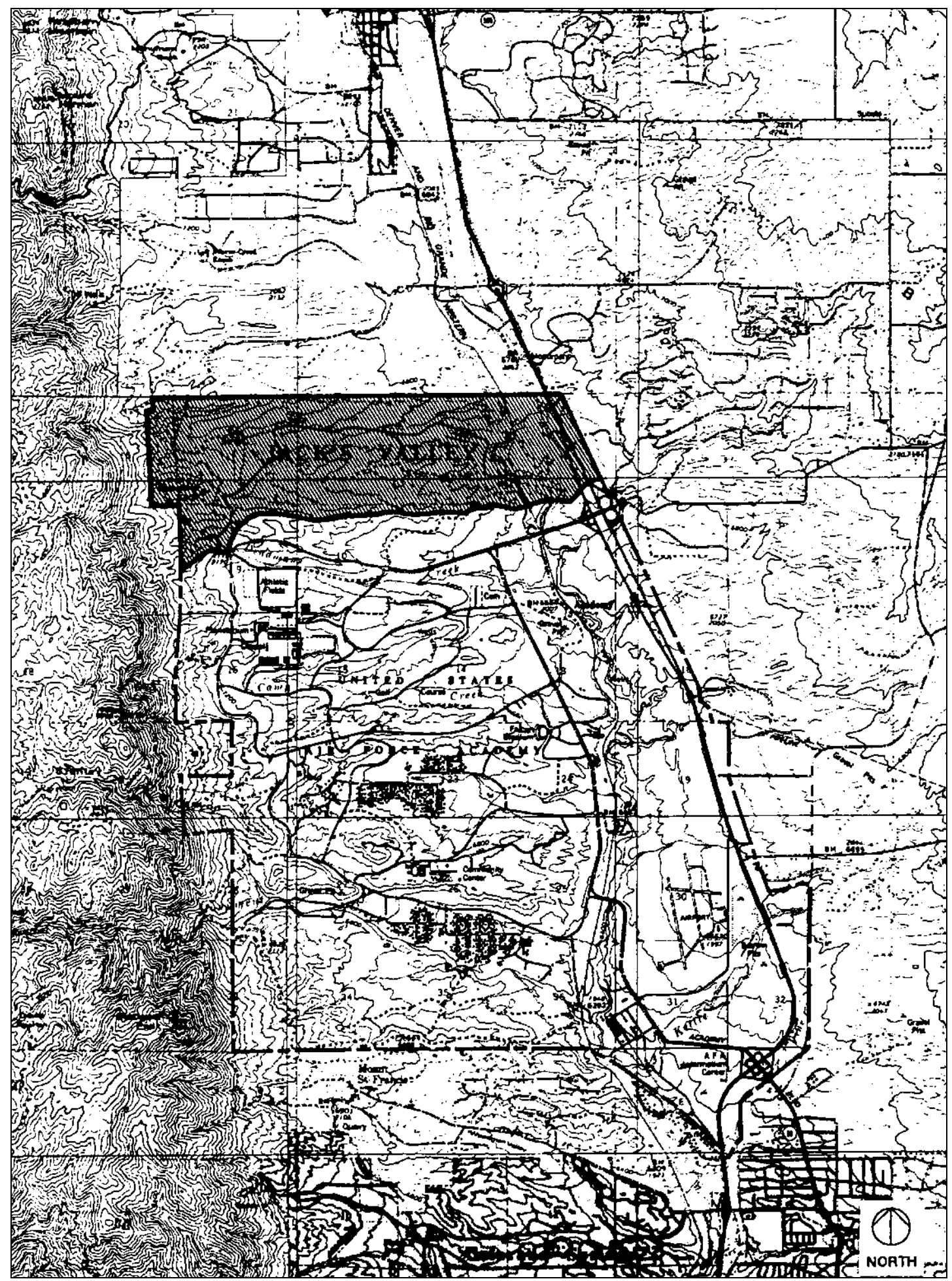

Figure 2. Map of the U.S. Air Force Academy showing Jack's Valley Training Area at the Academy's northern boundary (shaded). 


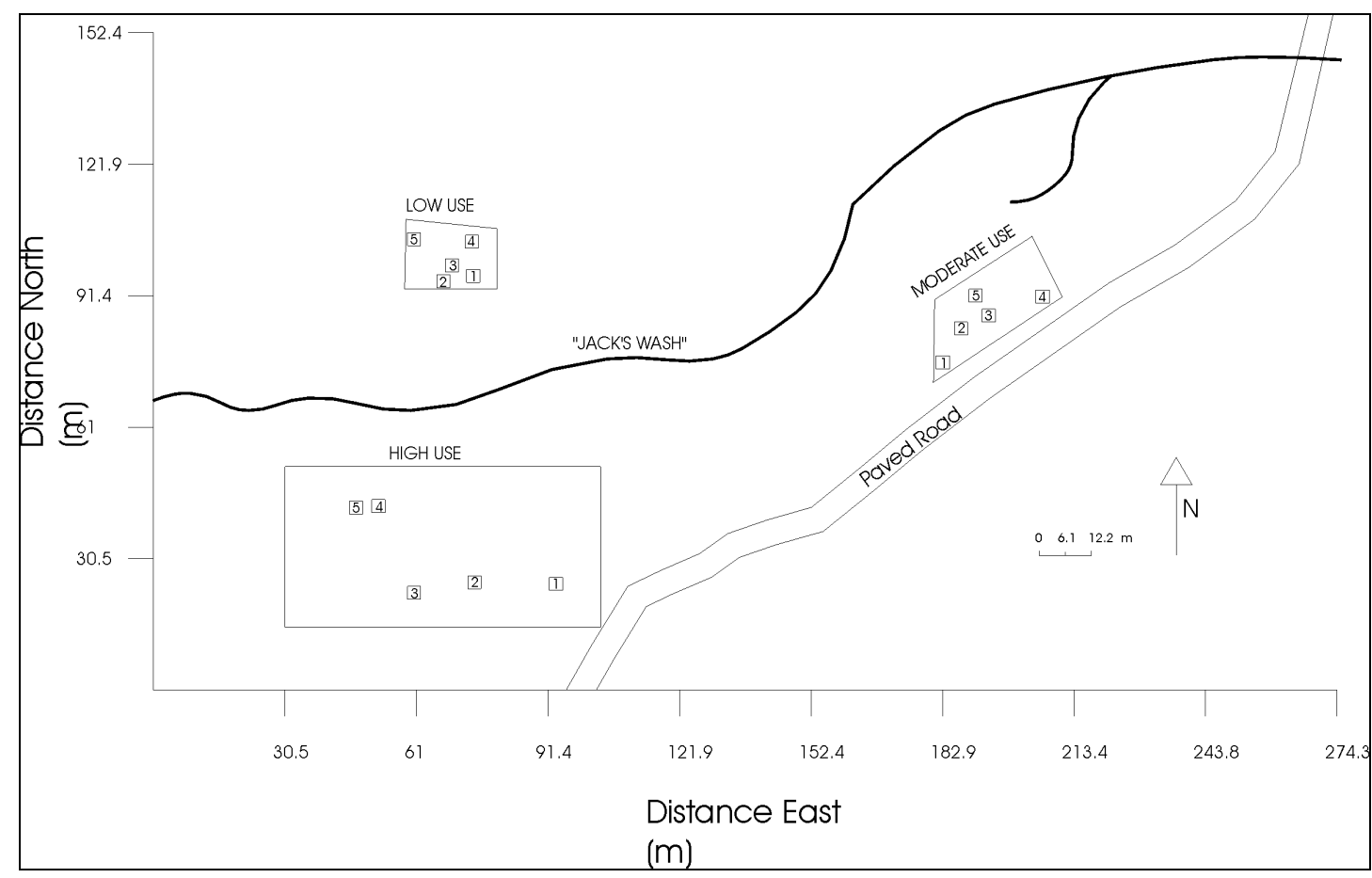

Figure 3. Map of the Research Area at Jack's Valley Training Area - three study sites are labeled as low use (reference), moderate use, and high use. The five subsamples within each site are numbered.

\section{Climate}

The climate of the area is characterized by warm summers and cold winters (Larsen 1981; Moore 1992). The annual average daily temperature is $9.4^{\circ} \mathrm{C}$ with an average daily minimum of $-7.8^{\circ} \mathrm{C}$ in the winter and an average daily maximum of $27.8^{\circ} \mathrm{C}$ in the summer. The majority of precipitation occurs in thunderstorms during the warm period; annual average precipitation is $40 \mathrm{~cm}$. Snowstorms are frequent during the winters. Average annual snowfall varies with elevation but ranges from $106 \mathrm{~cm}$ at lower elevations to $183 \mathrm{~cm}$ at higher elevations.

\section{Plant Communities}

JVTA includes seven primary plant communities: ponderosa pine woodland, ponderosa pine-Gambel oak woodland, Gambel oak shrubland, little bluestemblue grama grassland, smooth brome grassland, early-seral annuals/bare ground, and riparian edge along Monument Creek (McClendon and Childress 1997). The research area, though made up all of grassland communities, did not easily fit into these primary plant communities due to the training disturbances 
having induced successional diversity. The low use site contains native grassland and community type, Stipa-Koeleria species. The moderate use site contains early to mid-seral stage grassland/bare ground and a community type, Stipa-Koeleria species. The center of the high use site contains an early-seral stage grassland/bare ground and a community type, Bromus species. The edges of the high use site contain early to mid-seral stage grassland/bare ground and a community type, Stipa species.

\section{Soils}

The soils found on the research area are predominantly from the Pring series (coarse-loamy, mixed Aridic Haploborolls) but may also include to a minor extent soils from the Tomah series (coarse-loamy, mixed Boralfic Argiborolls) (Larsen 1981). The research area was mapped as Pring sandy loam although a few of the research plots had a loamy sand surface texture as does the Tomah series. Pring and Tomah soils are part of the soil association commonly found on cold, semiarid foothills of the Rocky Mountains to include fans, terraces, ridges, and side slopes. The soils are primarily deep, nearly level to slightly sloping, well-drained soils that formed in material weathered from arkosic sedimentary rock (Larsen 1981). Monroe and Wicander (1992) defined arkosic rock as sandstone having a feldspar content of at least 25 percent.

A typical Pring pedon has an A horizon with a dark grayish brown to brown color, coarse sandy loam texture, and a thickness of up to $25 \mathrm{~cm}$; an AC horizon with a light grayish brown color, sandy loam texture, and a thickness of up to 25 cm; and a $C$ horizon with a light gray, coarse sandy loam texture, and a thickness of $110 \mathrm{~cm}$ (Larsen 1981; U.S. Department of Agriculture [USDA] 1990). The depth to the bedrock is approximately 140 to $150 \mathrm{~cm}$. The sol um, the upper horizons of the soil where soil processes and biotic activities are most active, of a Pring soil ranges in thickness from 25 to $50 \mathrm{~cm}$. The permeability of the Pring soil is defined as rapid, the soil water holding capacity is described as medium, and surface runoff and the erosion hazard are both classified as moderate. Suitable land uses on the Pring soil include: homesites, rangeland, wildlife habitat, and recreation.

Included in the Pring series mapping unit is the Tomah series. A typical Tomah pedon has an A horizon with a dark grayish brown to light gray color, loamy sand texture, and a thickness of up to $56 \mathrm{~cm}$; a Bt horizon with a yellowish brown color, loamy sand texture, and a thickness of $66 \mathrm{~cm}$; and a $C$ horizon with a pale brown color, loamy sand texture, and a thickness of $30 \mathrm{~cm}$. The depth to the bedrock is approximately 140 to $150 \mathrm{~cm}$. The solum of a Tomah soil ranges in 
thickness from 100 to $150 \mathrm{~cm}$. The permeability of the Tomah soil is defined as moderately rapid; surface runoff is described as slow; the erosion hazard is classified as slight to moderate; and the soil water holding capacity is considered moderate. Suitable land uses on the Tomah soil include: homesites, rangeland, and wildlife habitat. Moderate to severe limitations exist for recreational use (Larsen; USDA 1991).

\section{Research Area}

The research area at JVTA is used primarily for a 16-day, basic cadet training field encampment during the summer months (Figure 3). In addition, JVTA is used year round for physical training, orienteering, and combat arms training by USAFA cadets, Army units from Fort Carson, Air Force Reserve, Air National Guard, Reserve Officer Training Corps cadets, federal, state, and local law enforcement agencies, and local organizations such as the Boy Scouts of America. The high use site is used for physical training and camping. This research area training usage information is based on USDI (1997), ENSR (1997), and personal conversations with USAFA personnel during the initial research area visit in May 1998.

\section{Low Use Site}

The low use reference site was located across an intermittent stream from the high and moderate use sites. The intermittent stream was blocked upstream by earthen dam designed for soil conservation purposes. Due to this physical separation, the low use reference site has recently experienced much less training activity than the test sites. Because of this increased seclusion, mammal activity is much higher on the reference site. Evidence of this increased mammal activity is the gopher midden strewn across the site. Deer frequently graze on the site. Historically, the low use site was plowed and farmed in the early 1900s, but this practice was soon discontinued due to the erosivity of the soils. Following the failed attempts at farming, the site was used primarily for grazing until the Academy was established in 1954. The slope of this site was gently sloping, 0 to 2 percent grade.

\section{Moderate Use Site}

The moderate use site was located downslope and near the high use site. Since 1996 it has been used mostly during J uly for the 16-day basic cadet training 
encampment period for physical training and some marching activities. Recently a truck conducted a U-turn across the site and left a noticeably compacted tire tread scar (note: soil sampling did not take place in this tire tread scar). Deer frequently graze on the site during periods of inactivity. Historically, this moderate use site was plowed and farmed in the early 1900s, but this practice was soon discontinued due to the erosivity of the soils. Following the failed attempts at farming, the site was used primarily for grazing until the Academy was established in 1954. The slope of this site was gently sloping, 0 to 1 percent grade.

\section{High Use Site}

The high use site has only been intensively used since 1996 for a 16-day period during J uly for basic cadet training encampment. This encampment supports 38 tents and approximately 450 cadets. In addition, over the rest of the year, but primarily during the summer months, the high use site has been used for 10 to 12 overnight encampments and many associated field exercises. Cadets have camped, marched, undertaken physical training, and filled sandbags on this site as well. As on the moderate use site, deer frequently graze on the site during periods of inactivity. As with the low and moderate use sites, the high use site also was plowed and farmed in the early 1900s, but this practice was soon discontinued due to the erosivity of the soils. Following the failed attempts at farming, the high use site was used primarily for grazing until the Academy was established in 1954. The slope of this site was gently sloping, 0 to 1 percent grade.

\section{Research Area Layout}

The research area was surveyed using a total station surveying instrument to find the sampling locations at a later time. Within each of the three sites, five plots (approximately $3 \mathrm{~m}$ by $3 \mathrm{~m}$ ) were randomly selected. The southwestern corner of each plot was sited using the total station. The other corners of the plot were then measured out by hand from the southwestern corner of the plot using a compass, an " $\mathrm{L}$ " square, and three measuring cords.

\section{Experimental Design}

Plant biomass, litter, and the following soil physical and chemical properties were measured: bulk density, texture, infiltration rate, total C concentration, total $\mathrm{N}$ concentration, and soil water holding capacity. Samples were collected 
for texture, total $\mathrm{C}$ concentration, and total $\mathrm{N}$ concentration in each site at three depths of: $0-5,5-10$, and $10-20 \mathrm{~cm}$. The sandy texture and lack of soil cohesiveness prevented the soil core method from being employed, so bulk density and soil water holding capacity samples were collected with a double-cylinder, hammer-driven core sampler at a depth of only 0-6 $\mathrm{cm}$.

Core samples at five randomly selected sampling locations within each plot were collected at each sampling depth for measurement of texture, total $\mathrm{C}$, and total $\mathrm{N}$. The 2-cm, small diameter sampling tube broke in the field, so it was used only on the high use site and part of the moderate use site, whereas a 3-cm, large diameter core was used on the remainder of the moderate use site and the low use site. Samples were collected in the same sampling locations for bulk density. Soil water holding capacity was determined on two of the five sampling locations at each site. Bulk density samples were collected again during a second trip later that summer following the 16-day basic cadet training encampment. Each core sample (for texture, total $\mathrm{C}$, and total $\mathrm{N}$ ) at a given depth collected within the plot was later combined in the laboratory to reduce variability due to the heterogeneity within the plot. Seventy-five core samples were collected for texture, total C, and total N; 75 double-cylinder, hammer-driven cores were collected to a depth of $6 \mathrm{~cm}$ for bulk density (both pre and post-encampment); 30 double-cylinder, hammer-driven cores were also collected at a depth of $6 \mathrm{~cm}$ for soil water holding capacity; and 18 infiltration rate trials were conducted (6 per site).

\section{Soil Preparation}

Soil preparation procedures for texture, total $\mathrm{C}$, and total $\mathrm{N}$ analyses were described by the U.S. Environmental Protection Agency (USEPA 1990). First, samples were dried on polyvinyl chloride (PVC) tables and heavy nylon mesh (drying was not conducted on bulk density or soil water-holding capacity samples). Once air-dried, samples were disaggregrated, ground by a rolling pin, and sieved over kraft paper sheets. After sieving, the samples were subsampled prior to the analysis in order to obtain a representative volume of soil.

\section{Bulk Density}

Soil compaction was assessed as a function of bulk density. Blake and Hartge (1986) defined bulk density as the mass of the dry soil solids per soil bulk volume (which included the volume of the pore space as well as the volume of the soil solids). Bulk density was determined by the double-cylinder, hammer-driven 
core method. A cylindrical metal core sampler with an internal brass ring was driven into the soil to a 6-cm depth. In the laboratory, the sample was weighed and then oven-dried at $105{ }^{\circ} \mathrm{C}$ overnight to achieve a constant weight. The ovendry mass was divided by the sample volume to give a bulk density (Blake and Hartge 1986). This procedure was undertaken twice: once before the third, 16day basic cadet training encampment (pre-encampment) and once following the third, 16-day basic cadet training encampment (post-encampment).

\section{Infiltration}

Infiltration rate was measured using a singlering cylinder infiltrometer. Infiltration rate was defined by Bouwer (1986) as the volume flux of water moving into the soil surface per unit area. Two repetitions were conducted in the first plot of each site to standardize the techniques across the sites and to ensure leakage was not occurring; otherwise, one repetition of the experiment was conducted within each plot. Litter and vegetative cover were recorded prior to placement of infiltrometer. The cylinder infiltrometer, which had a 12-cm diameter and a 12-cm height, was carefully placed into the soil to an approximate depth of $3 \mathrm{~cm}$. The cylinder was flooded with water to saturate the soil. Burlap was placed over the soil surface before water was poured into the infiltrometer to prevent disturbance of the soil. The rate at which the water was absorbed into the soil was determined by maintaining a constant depth of water within the infiltrometer and recording the time (USDA 1998).

\section{Texture}

Texture, the relative proportion of sand, silt, and clay, was determined by particle-size analysis using a hydrometer (Gee and Bauder 1986). Percent clay was determined using the hydrometer; percent gravel and sand were determined by sieving dispersed soil (after clay measurement) through a $0.053 \mathrm{~mm}$ ( 270 mesh) sieve and weighing oven-dried material; and percent silt was the difference. An ultrasonic sieve device was used to determine different sand sizes.

\section{Soil Water-Holding Capacity}

Soil water-holding capacity, which was assessed as a measure of the availability of water for plant uptake, was measured using the pressure plate method. Pressure was applied to a soil sample placed on a porous pressure plate at $0.10,0.33$, or 15.0 bars of pressure. Each sample was subsampled, placed in a rubber 
retaining ring, on the appropriate pressure plate, saturated overnight, equilibrated in the pressure plate apparatus overnight at the corresponding pressure, weighed, oven-dried at $105^{\circ} \mathrm{C}$ overnight, and then weighed again. Field capacity represented the amount of water retained by a soil when subjected to water pressure of less than 0.33 bars (both 0.10 and 0.33 bars in this experiment), whereas the permanent wilting point represented the amount of water retained by a soil when subjected to 15 bars of pressure (Klute 1986).

\section{Soil Total Carbon and Nitrogen Analysis}

After initial soil preparation was completed at the University of Illinois at Urbana-Champaign, samples were sent to the Colorado State University Soil Testing Laboratory for total $\mathrm{C}$ and total $\mathrm{N}$ analysis. Total $\mathrm{C}$ and $\mathrm{N}$ concentrations in soil samples were determined using an elemental analyzer. The soil sample was oxidized in the analyzer at a temperature greater than $1000{ }^{\circ} \mathrm{C}$. The amounts of $\mathrm{CO}_{2}$ and $\mathrm{N}_{2}$ gases produced from the reaction were then quantified by infrared spectroscopy (USEPA 1990). Simple linear regression was run to determine if total carbon concentration was related to total nitrogen concentration. If a relationship between total carbon and nitrogen concentrations existed, then the carbon present in the soil was assumed to be in an organic form.

\section{Plant Biomass and Litter}

Under the direction of Dr. McClendon's research team, plant biomass and litter samples were collected across the research area. Four, 10 by $10 \mathrm{~m}$ plots were established in the research area to capture the differing grassland communities and intensities of use: a high use plot in the center of basic cadet training encampment area, another high use plot at the edge of encampment area, a plot within the moderate use site, and a plot within the low use site. Two quadrats (each $0.5 \mathrm{~m}^{2}$ ) were randomly placed across each of the five transects within a plot. The vegetation was identified, clipped, composited by species, oven-dried at $50{ }^{\circ} \mathrm{C}$ overnight to achieve a constant weight, and then weighed to determine the species-specific biomass $\left(\mathrm{g} \mathrm{m}^{-2}\right)$ within each quadrat. Litter was also collected within each quadrat, oven-dried at $50{ }^{\circ} \mathrm{C}$, and weighed. Vegetative species and litter samples across each plot were composited. The appropriate lifeforms of the species were later identified to compare the effects of the basic cadet training activities on the lifeforms. 


\section{Soil Erosion}

The Universal Soil Loss Equation (USLE) was used to estimate rates of soil erosion occurring on the research area. USLE is defined as $A=R \times K \times L \times S \times C \times P$, where $A$ is the gross erosion rate, $R$ is the rainfall erosivity factor, $K$ is soil erodibility factor, $\mathrm{L}$ is the slope-length factor, $\mathrm{S}$ is the slope-steepness factor, $\mathrm{C}$ is the vegetation factor, and $\mathrm{P}$ is the conservation management factor (Wischmeier and Smith 1960). The USLE factors were determined for each plot based on the measured soil properties collected at the research area (e.g., K, L, and S) or obtained from the USDA (1994) for local values (e.g., R, C, and P). A standardized plot size of 1 ha was used in computing the gross erosion rate, $A$.

\section{Data Analysis and Interpretation}

Using the SAS statistical package, one-way analysis of variance (ANOVA) with subsampling and Tukey's studentized range tests* were conducted on the measured properties. Statistical significance for ANOVA and mean separation was determined using a $p$-value of 0.05 . The design of the ANOVA included a dependent variable (e.g., one of the measured properties: bulk density, texture, infiltration rate, soil water holding capacity, total $\mathrm{C}$, total $\mathrm{N}$, the ratio of total $\mathrm{C}$ to total $\mathrm{N}$, and total aboveground biomass) and one of two independent variables (disturbance or depth). The statistical analysis was used to assess the impacts of the basic cadet training encampment and other training on the potential for soil erosion occurring on these training sites. The results were then passed on to Dr. McClendon's research team for application in the EDYS model as a portion of the data used to calculate the carrying capacity of J VTA.

* Tukey's studentized range test is a means separation test. 


\section{Results and Discussion}

\section{Bulk Density}

During J uly of 1996, 1997, and 1998 the research area had been used for a 16day basic cadet training encampment, with other less intensive training use occurring throughout the year. Bulk density samples were collected in May-J une 1998 prior to the J uly 1998 basic cadet training encampment (pre-encampment samples) and in August 1998 following the J uly basic cadet training encampment (post-encampment samples).

The pre-encampment samples were compared to determine whether the amount of site usage affected the bulk density. The low use site had a mean bulk density of $1.04 \mathrm{~g} \mathrm{~cm}^{-3}$, which was significantly lower than the bulk densities of the moderate use site (mean bulk density, $1.30 \mathrm{~g} \mathrm{~cm}^{-3}$ ) and the high use site (mean bulk density, $1.37 \mathrm{~g} \mathrm{~cm}^{-3}$ ) (Figure 4). The bulk densities of the high and moderate use sites were not significantly different. These results are similar to findings of Monti and Mackintosh (1979) and Trumbull et al. (1994) that camping increases soil bulk densities. Trumbull et al. (1994) likewise found no significant differences between the bulk densities on low use and high use campsites. Although the use categories are subjective, it is safe to assume Trumbull et al.'s (1994) application of the low use definition is comparable to our moderate use site and their control is similar to our low use site (our reference).

A high use plot with one of the higher pre-encampment mean bulk densities, $\mathrm{H}$ 2 , located in the center of the basic cadet training encampment area (Figure 3), had a mean bulk density of $1.46 \mathrm{~g} \mathrm{~cm}^{-3}$. The highest bulk densities were found in the center of the basic cadet training encampment area, which was also what Cole (1982) found. One low use plot with a lower pre-encampment mean bulk density, L-3, had a mean bulk density of $1.02 \mathrm{~g} \mathrm{~cm}^{-3}$. Both plots had a sandy loam soil texture. This high use plot had a pre-encampment mean bulk density 30 percent greater than the pre-encampment mean bulk density of the low use plot. Dotzenko et al. (1967) found mean bulk density differences between high and low use campsites ranged from 30 to 55 percent whereas Monti and Mackintosh (1979) found a 34 percent difference. The study by Dotzenko et al. occurred on high use campsites that had experienced intensive camping use for over 30 years, whereas the high use plot studied here had experienced only 3 years of 
intensive camping use. The 30 percent difference in mean bulk densities between high and low use plots measured at the J VTA research area compared to the low end of the increase Dotzenko et al. (1967) measured at Rocky Mountain National Park.

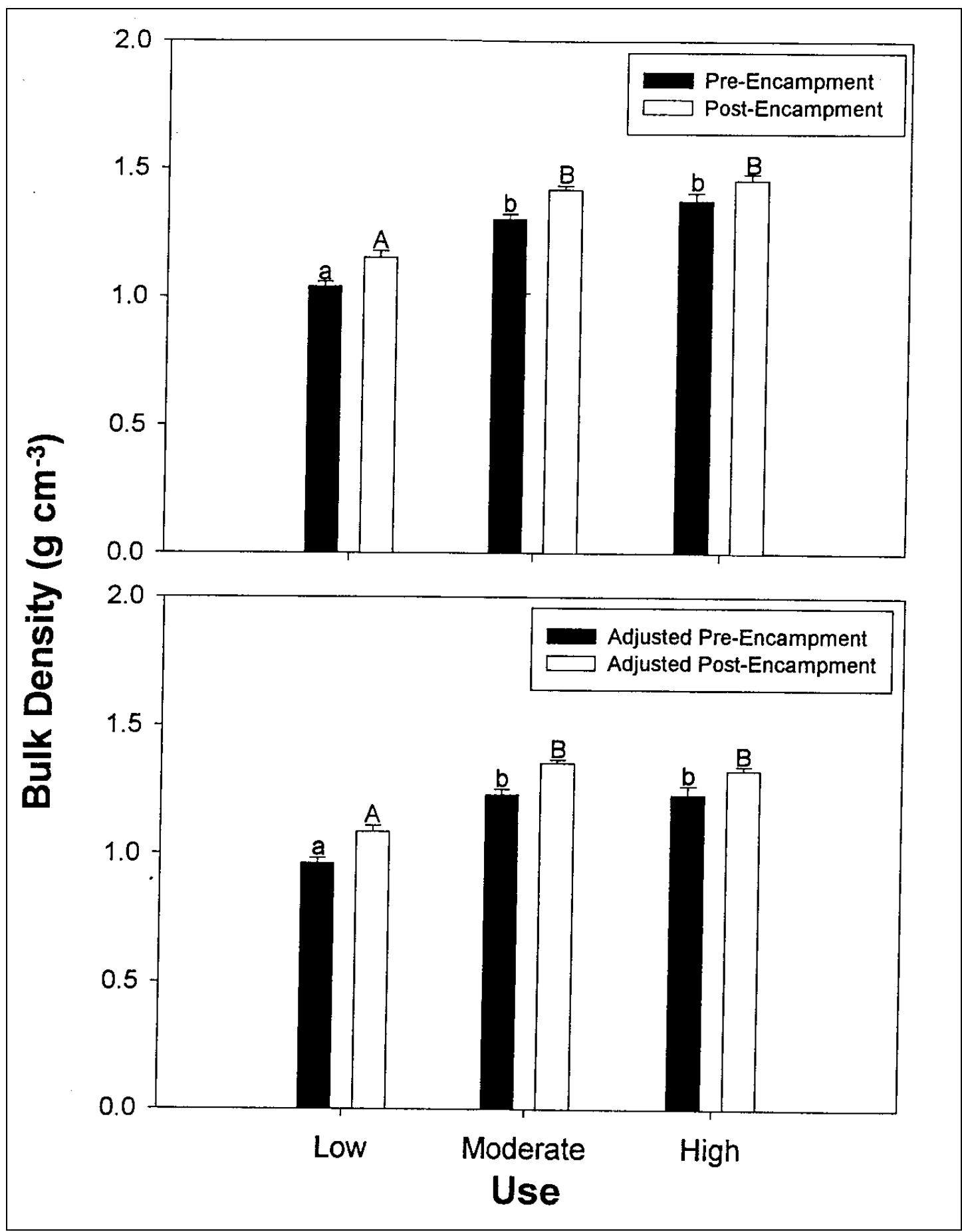

Figure 4. Pre- and post-encampment mean soil bulk densities and adjusted soil bulk densities (with standard errors, $n=25$, and adjusted for coarse fragments) for grassland soils at the USAFA JVTA based on intensity of use. Means with same letter and case style are not significantly different $(p>0.05)$. 
The post-encampment samples were also compared to determine if site usage over the 16-day basic cadet training encampment affected bulk densities. For the post-encampment samples, the low use site had a mean bulk density of 1.15 $\mathrm{g} \mathrm{cm}^{-3}$, which was significantly lower than the bulk densities of both the moderate use site (mean bulk density, $1.42 \mathrm{~g} \mathrm{~cm}^{-3}$ ) and the high use site (mean bulk density, $1.46 \mathrm{~g} \mathrm{~cm}^{-3}$ ). The bulk densities of the high and moderate use sites were not significantly different. The post-encampment results also concurred with past research findings of camping increasing bulk densities (Monti and Mackintosh 1979; Trumbull et al. 1994). The lack of significant difference between both the pre-encampment and the post-encampment moderate use site and high use site mean bulk densities indicates that even a small amount of use (i.e., moderate use site) degraded a training site equally as much as a large amount of use (i.e., high use site).

The same high use plot discussed earlier, $\mathrm{H}-2$, had a post-encampment mean bulk density of $1.50 \mathrm{~g} \mathrm{~cm}^{-3}$. The low use plot, L-3, had a post-encampment mean bulk density of $1.08 \mathrm{~g} \mathrm{~cm}^{-3}$. This high use plot had a post-encampment mean bulk density 28 percent greater than the post-encampment mean bulk density of the low use plot.

To assess whether site usage during the 16-day basic cadet training further affected soil bulk densities, the pre-encampment and post-encampment bulk densities were compared. A t-test indicated that the pre-encampment bulk densities for each of the site usage classes were significantly different from the postencampment bulk densities. These results indicate that the 16-day basic cadet training encampment activities further increased the bulk densities on all three sites. In an ideal experimental design, the reference site would have been undisturbed. The low use reference site in this research project, however, was subjected to a small amount of training use during the third basic cadet training encampment, which could explain the increase in the mean bulk density on the reference site.

To discount any variation in bulk densities due to coarse fragment content of the soil, the coarse fragment content of each sample was subtracted and an adjusted bulk density was then calculated (Figure 4). The statistical analysis indicated that when adjustments were made for coarse fragment contents the low use adjusted bulk densities were significantly different from the moderate and high use adjusted bulk densities for both pre- and post-encampment samples. In addition, the pre-encampment adjusted bulk densities were still found to be significantly different from post-encampment adjusted bulk densities. Therefore, there was not any effect due to the differing coarse fragment contents of the two soil types, 
and basic cadet training encampment activities did increase bulk density and compaction on the sites.

\section{Texture}

Soil texture is a crucial indicator of a soil's susceptibility to compaction (Reed 1983). Representative soil samples for each of the three depths (0-5, 5-10, and 10-20 cm) were analyzed by particle size analysis to determine the grassland soil surface textures across the research area (Figure 5). The texture of the soils in the plots at the high use site was sandy loam, which is the same texture as the surface horizon of the Pring soil (Larsen 1981). Three of the five plots within the moderate use site were the sandy loam soil, whereas, the remaining two plots were loamy sand soils, which is the same texture as the surface horizon of the Tomah soil (Larsen 1981). Tomah soil is hypothesized to be an inclusion in the Pring soils of the grassland research area as mapped by Larsen (1981). For the low use site, three of the five plots were the sandy loam soil, whereas the remaining two plots were the loamy sand soil. Although there was a little variation in the soil textures across the research area, analysis indicated no significant effect.

The clay content was determined as part of the particle size analysis procedure. Site usages were compared by clay content to determine whether day content was related to the increased bulk density using ANOVA and Tukey's studentized range tests. The difference in clay contents between the different site usages was not significant. The site usages were also compared by coarse fragment content. The difference in coarse fragment contents between the different site usages was also not significant. Therefore, effects on increased bulk densities due to the clay content and due to the coarse fragment content were not found. 


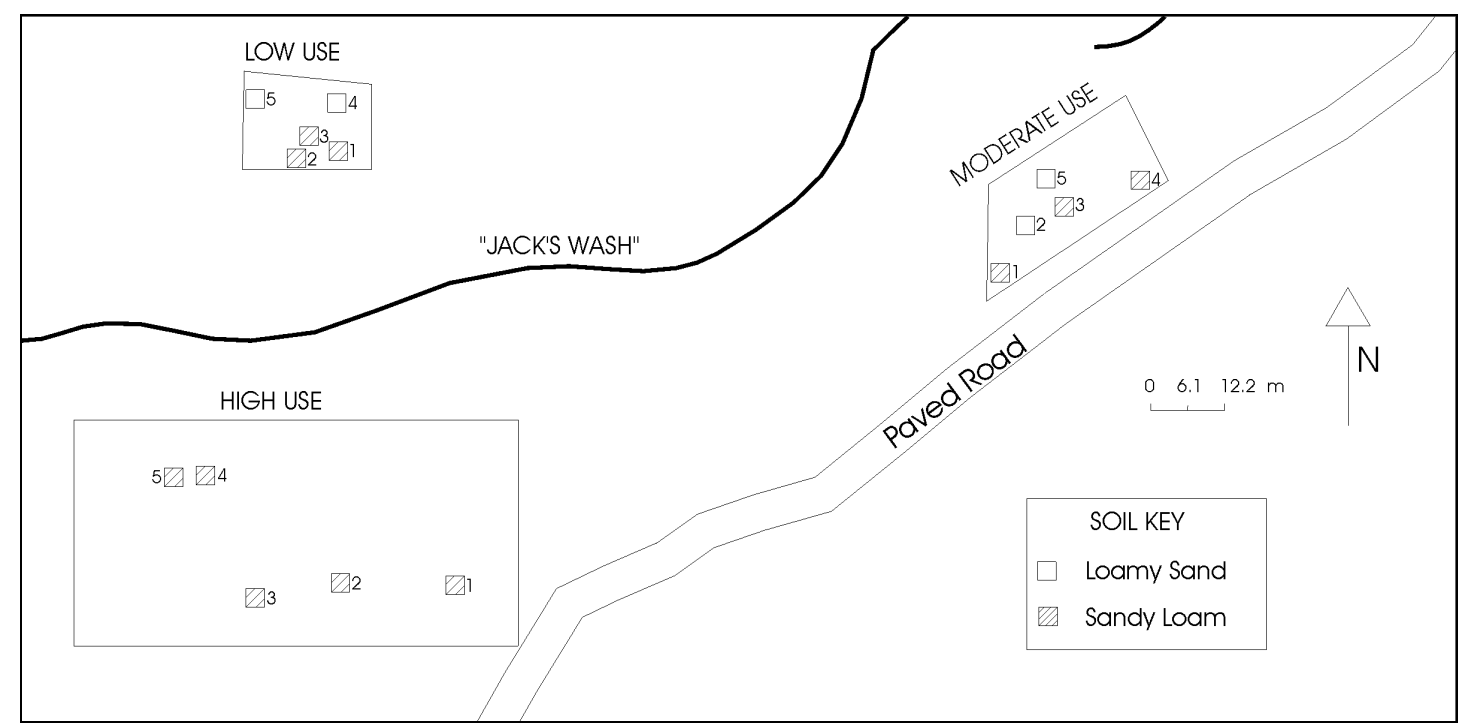

Figure 5. Map of soil surface textures across the grassland soil research area at the USAFA's JVTA based on particle size analysis results.

\section{Infiltration}

Infiltration, as with bulk density, is a measure of compaction. Infiltration rates were measured across the research area. Infiltration rates at the low use site (mean rate, $3.83 \mathrm{~cm} \mathrm{~min}^{-1}$ ) were significantly higher than the rates at the moderate use site (mean rate, $0.67 \mathrm{~cm} \mathrm{~min}^{-1}$ ) and the high use site (mean rate, $0.63 \mathrm{~cm}$ $\left.\mathrm{min}^{-1}\right)$ (Figure 6). The infiltration rates of the high and moderate use sites were not significantly different. Therefore, these results support the findings of Trumbull et al. (1994) that infiltration rates significantly decreased on recreational sites.

Monti and Mackintosh (1979) measured infiltration rates at recreational sites 20 to 30 times lower than the infiltration rates at control sites. The mean infiltration rate from the low use grassland soil at the Academy was six times greater than the moderate and high use sites. Although this difference was not as large as that measured by Monti and Mackintosh (1979), it matched what Lutz (1945) reported from his studies on sandy soils where infiltration rates on high use sites decreased by six times when compared to the control sites.

There were several possible reasons for the higher infiltration rate found on the low use site. First, as stated by Dunne and Leopold (1996), the decrease in vegetative cover due to land use changes caused large differences in infiltration on similar soil types. Second, Dawson et al. (1978) found soil macropore space was 18 percent lower than on campsites than on the control site. 


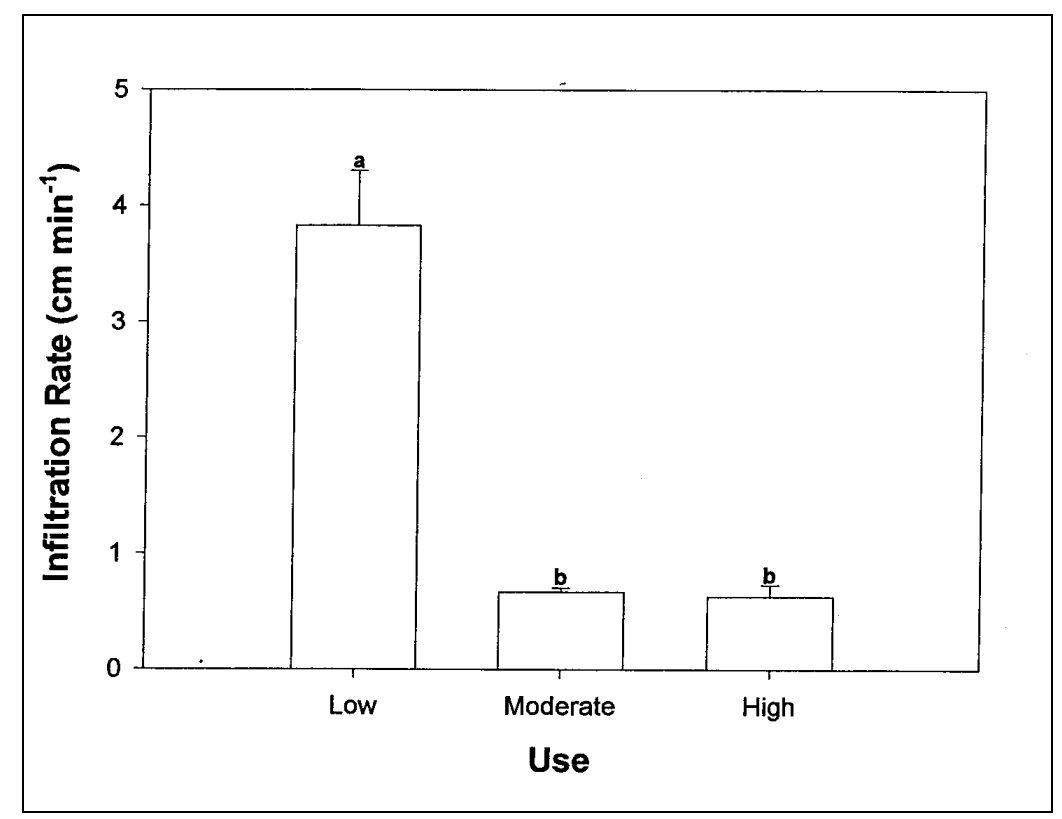

Figure 6. Mean infiltration rates (with standard errors) for grassland soils at the USAFA JVTA based on intensity of use. Means with the same letter are not significantly different ( $p>0.05)$.

Another factor affecting infiltration rates may have been macrofaunal activity. Gopher activity on the low use site was extremely high as shown by the large amount of gopher burrow midden that was present throughout the entire low use site. No gopher midden was found on either the moderate or high use site. Gopher burrows, which function as soil macropores, serve to increase infiltration (Pritchett and Fisher 1987). Macropores are where capillary forces are minimized and gravitational forces predominate allowing water to infiltrate into the soil faster. A feedback probably existed on the low use site where the lack of human recreational activity encouraged mammal activity, which in turn contributed to improved infiltration on the low use site. Reasons for this significant difference in mean infiltration rates included the greater surface vegetative and litter cover, the lower bulk density, the greater porosity, and the large number of gopher burrows on the low use site.

\section{Soil Water-Holding Capacity}

Soil water-holding capacity is defined as the relationship between the "soil water content and the soil water suction" (Klute 1986). It is important as a measure of the availability of water in the soil for plant uptake. Mean soil water-holding capacities of the low use site were not significantly different from the mean soil water-holding capacities of either the moderate use or high use sites. Based on intensity of use, water retention curves were made by plotting the mean water contents against the three different pressures in the laboratory (Figure 7). In 
addition to the lack of a significant difference between the mean soil waterholding capacities among the sites, these three moisture retention curves based on intensity of use were quite similar. Therefore, the intensity of use did not impact the soil water-holding capacity of the grassland soils in the research area.

The moisture retention curves showed that most water was drained out of the pores with relatively little pressure ( 0.33 bars, field capacity) being applied. This rapid draining of the macropores was expected due to the coarse texture of these soils. Coarse textured soils contain large numbers of macropores where gravitational forces easily drain the water. Little water remained in the pores as available water of the samples between 0.33 bars (field capacity) and 15 bars (permanent wilting point).

Plot H3 (Figure 3), the center of basic cadet training encampment activity and also the most compacted plot, had a lower gravimetric water content at all 3 pressures than all the other 14 plots. The large differences in mean soil waterholding capacities that existed between the $\mathrm{H} 3$ plot and the 14 other plots supported the research by Dunn et al. (1980) in that soil water-holding capacity and pore space were decreased by recreational trampling on sandy loams. Without further replication of the research comparing the center of basic cadet training encampment activity to the other plots, no definitive relationship of the center of basic cadet training encampment activity to soil water-holding capacity can be made.

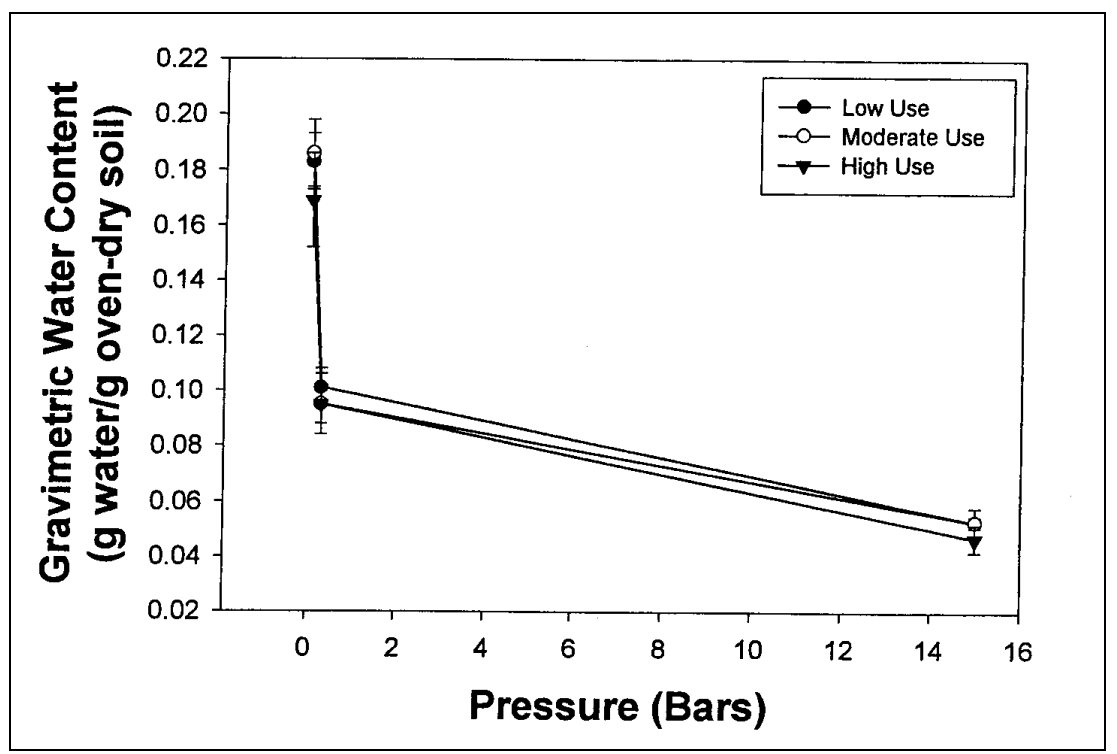

Figure 7. Moisture retention curves (with standard errors) for grassland soils $(0-5 \mathrm{~cm})$ at the USAFA JVTA based on intensity of use. Pressure was applied at three different pressures 0.10 bars, 0.33 bars (field capacity), and 15 bars (permanent wilting point). 


\section{Soil Total Carbon and Nitrogen Analysis}

In most surface soils, carbon and nitrogen are in organic forms. Therefore, there should be a linear relationship between carbon and nitrogen. In this study, a simple linear regression was run to determine if total $C$ concentration was related to total $\mathrm{N}$ concentration. A strong relationship $(\mathrm{r} 2=0.92, \mathrm{n}=75)$ was found between total $\mathrm{C}$ concentration and total $\mathrm{N}$ concentration, so the total $\mathrm{C}$ fraction was assumed to be in an organic form (F igure 8).

Interestingly, both total $\mathrm{C}$ concentrations and total $\mathrm{N}$ concentrations decreased with depth in all samples collected across the research area except in the center of basic cadet training encampment, plot $\mathrm{H} 3$. In this plot, concentrations were nearly equal at the 0 to 5 and 10 to $20 \mathrm{~cm}$ depths, yet highest at the 5 to $10 \mathrm{~cm}$ depths. Further research would be required to establish a statistically significant trend. Reasons for this pattern, however, could include the surface horizon having been eroded away and/or soils with lower concentrations of carbon and nitrogen having been dropped on top of the surface of the existing soil while sandbags were being made or set in place.

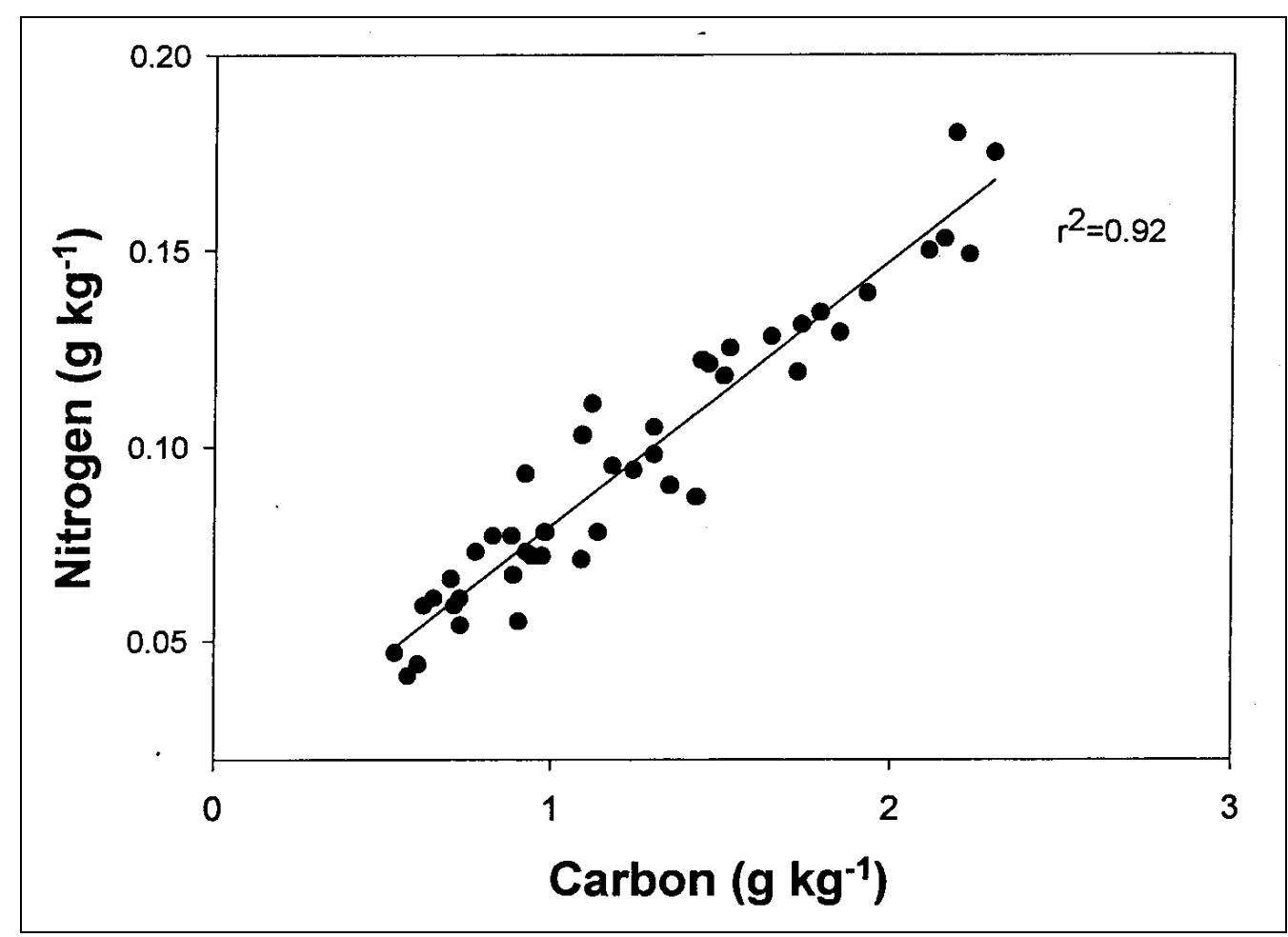

Figure 8. Simple linear regression of total carbon concentration to total nitrogen concentration (with $r^{2}$ value, $n=75$ ) for grassland soils at the USAFA's JVTA. 
The total $\mathrm{C}$ concentration, total $\mathrm{N}$ concentration, and the $\mathrm{C}: \mathrm{N}$ ratio were all compared by depth $(0-5,5-10,10-20 \mathrm{~cm})$ using ANOVA and Tukey's studentized range tests based on the different intensities of use to determine whether the amount of site usage affected the nutrient composition. At the 0 to 5 and 5 to 10 $\mathrm{cm}$ depths, the mean total $\mathrm{C}$ concentration of the low use site (1.83 and $1.17 \mathrm{~g}$ $\mathrm{kg}^{-1}$ respectively) was not significantly different from either the mean total $\mathrm{C}$ concentration of the moderate use site (1.80 and $1.0 \mathrm{~g} \mathrm{~kg}^{-1}$ respectively) or the high use site (1.72 and $1.25 \mathrm{~g} \mathrm{~kg}^{-1}$ respectively) (Figure 9). At the 10 to $20 \mathrm{~cm}$ depth, the mean total $C$ concentration of the high use site $\left(0.67 \mathrm{~g} \mathrm{~kg}^{-1}\right)$ was significantly different from the mean total $C$ concentration of the low use site $\left(0.93 \mathrm{~g} \mathrm{~kg}^{-1}\right)$. This difference between the mean total $C$ concentrations of the high use and low use sites based on intensity of use, however, was not meaningful as no pattern existed to explain the difference at this depth of 10 to $20 \mathrm{~cm}$. At all three depths, the mean total $\mathrm{N}$ concentration of the low use site $\left(0.13,0.09\right.$, and $0.07 \mathrm{~g} \mathrm{~kg}^{-1} \mathrm{re}$ spectively) was not significantly different from either the mean total $\mathrm{N}$ concentration of the moderate use site $\left(0.14,0.09\right.$, and $0.07 \mathrm{~g} \mathrm{~kg}^{-1}$ respectively) or the high use site $\left(0.12,0.1\right.$, and $0.05 \mathrm{~g} \mathrm{~kg}^{-1}$ respectively). At the 0 to $5 \mathrm{~cm}$ depth, the $\mathrm{C}: \mathrm{N}$ ratio of the low use site $\left(16.6 \mathrm{~mol} \mathrm{~mol}^{-1}\right)$ was not significantly different from the $\mathrm{C}: \mathrm{N}$ ratios of the moderate use site $\left(14.8 \mathrm{~mol} \mathrm{~mol}^{-1}\right)$ or the high use site $(16.4$ mol mol ${ }^{-1}$ ). At the 5 to 10 and 10 to $20 \mathrm{~cm}$ depths, the $C: N$ ratio of the moderate use site (12.7 and $12.4 \mathrm{~g} \mathrm{~mol} \mathrm{~mol}^{-1}$ respectively), however, was significantly different from the $\mathrm{C}: \mathrm{N}$ ratio of the low use site $\left(15.5\right.$ and $16.4 \mathrm{~g} \mathrm{~mol} \mathrm{~mol}^{-1}$ respectively) and the high use site (15.1 and $14.9 \mathrm{~g} \mathrm{~mol} \mathrm{~mol}^{-1}$ respectively). This difference between the $\mathrm{C}: \mathrm{N}$ ratios based on intensity of use, however, was not meaningful as no pattern existed to explain the difference. Therefore, the intensity of use did not affect nutrient composition on these grassland soils.

\section{Plant Biomass and Litter}

The research area is composed of basically three grassland communities: the low use site contains a native grassland community type, Stipa-Koeleria species; the moderate use site and the edges of the high use site contain early to mid-seral stage grassland/bare ground and a community type, Stipa-Koeleria species (Stipa species for the edges of the high use); the center of the high use site contains an early-seral stage grassland/bare ground and a community type, Bromus species. 


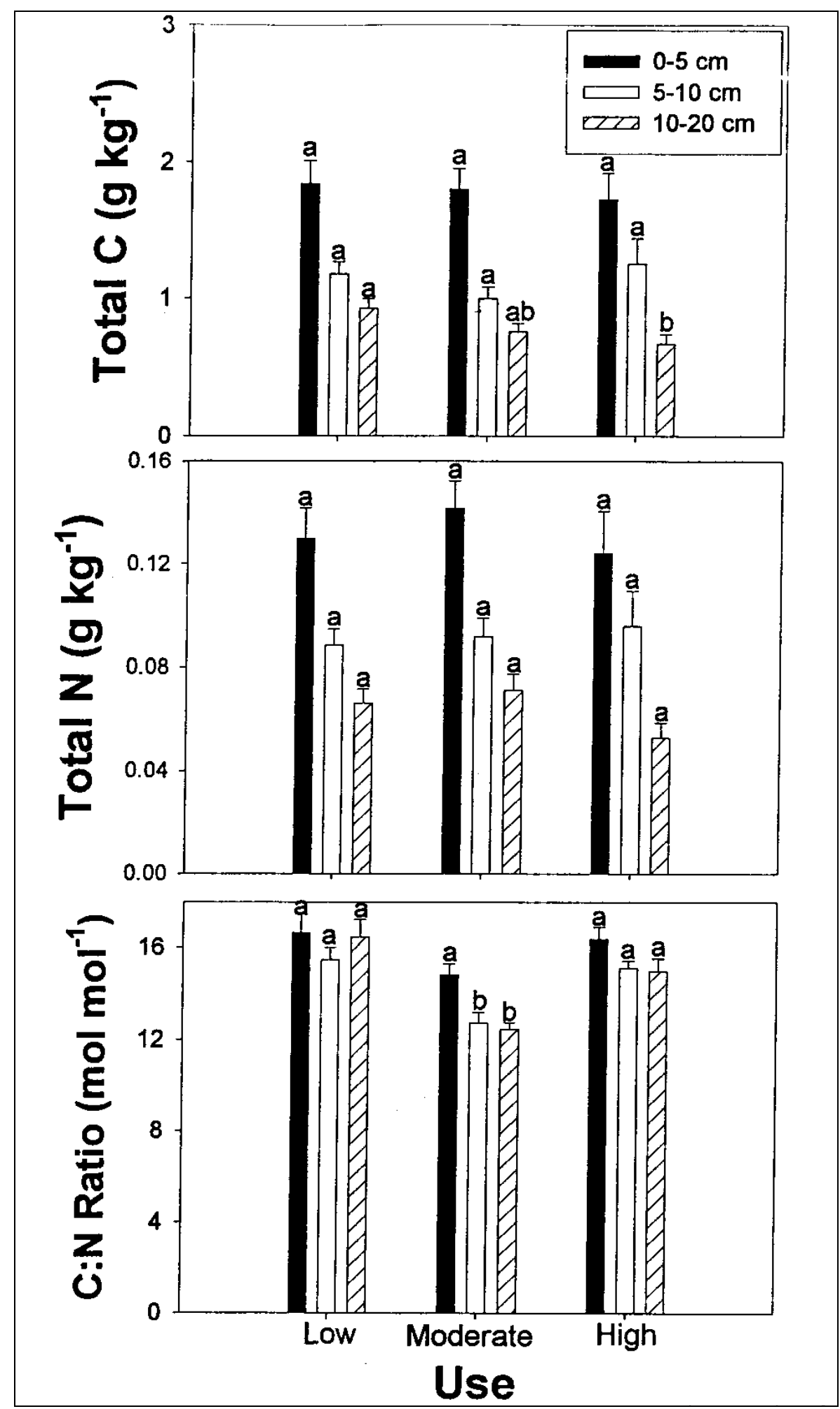

Figure 9. Mean total carbon concentration, total nitrogen concentration, and ratio of total carbon to total nitrogen concentration (with standard errors) for grassland soils at USAFA's JVTA based on intensity of use. Means within a depth and with same letter are not significantly different $(p<0.05)$. 
Because the entire biomass of a species within the pl ot was composited, statistical analysis could not be conducted. Graphical and descriptive comparisons of the total aboveground biomass and litter were only used, however, to compare the impacts of the differing intensities of use (Figure 10). These results reinforced the findings of Monti and Mackintosh (1979) and Dunn et al. (1980) in that recreational activity denuded vegetation and the litter layer on the campground. Dunn and Carroll (1985) found recreational use decreased vegetation and litter by 56 percent. They also found that the center of campsites were more denuded than the rest of the camping area. Research on Illinois campsites found litter layers decreased by 71 percent (Young 1978). The research findings from the Academy even exceed Dunn and Carroll's (1985) measured decrease in vegetation and litter and Young's measured decrease in litter layer. A comparison between the low use and the high use plots in the center of the basic cadet training encampment area showed a 68 percent decrease in total aboveground biomass and a 91 percent decrease in litter. A comparison between the low use plot and both the moderate use plot and the high use plot on the edge of the encampment area showed less of a difference, but still a large difference, of a 40 percent decrease in total aboveground biomass and a 75 percent decrease in litter. Based on past research, possible reasons for this drastic denudation of vegetation and litter from the moderate and high use sites included the actual mechanical trampling of vegetation by the cadets (Dunn 1984), the moderate impact from the lug-soled boots used by the cadets (Cole 1995b); the kicking up of gravel damaging the vegetation (especially on the high use plots $\mathrm{H} 2$ and $\mathrm{H} 3$ in the center of the basic cadet training encampment area, where coarse fragment content was high) (Dunn 1984); and the apparent relationship of the absence of roots in the surface horizon to the high bulk densities in the surface horizons, as found on the high and moderate use sites.

Wagar (1964) found that, grasses were more tolerant than broad-leaved species to recreational trampling. Yorks et al. (1997) reported that, following recreation, forbs suffered immediate loss, and shrubs and trees decreased in long-term diversity. A comparison between the low use plot and the high use plot-center of the encampment area showed a 78 percent decrease in forb biomass. A comparison between the low use plot and the moderate use plot showed a 76 percent decrease in forb biomass. As suggested by the research of Dawson et al. (1978) and Dunn et al. (1980), the basic cadet training encampment activities and other training use induced disturbance, which led to the early-seral annuals/bare ground communities found on the high and moderate use sites. Though statistically unsubstantiated, it appeared the basic cadet training activities on the test sites drastically denuded the vegetative cover and litter layer, and reduced the lifeform diversity. 


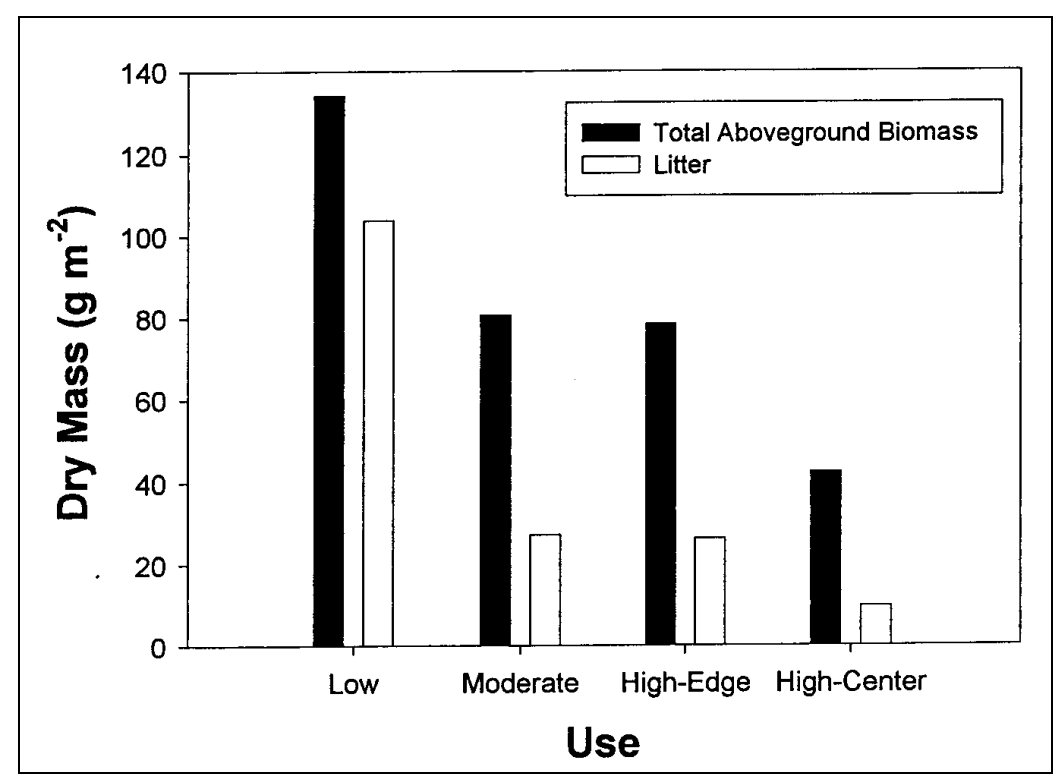

Figure 10. Comparison of total aboveground biomass and litter for grassland soils at USAFA's JVTA based on intensity of use (high use site divided into two plots: a plot in the center of basic cadet training encampment area and a plot at the edge of encampment area).

\section{Soil Erosion}

Due to the pseudo-replication in the experimental design of this research, these results cannot be applied outside of the research area without additional study. Past research findings, however, support the findings of this research that human trampling activities lead to increased bulk densities, decreased infiltration, and decreased plant biomass and litter. Therefore, the impacts of cadet and other uses found during this research effort and supported by past research can lead to additional research and application in principle only.

The research on the grassland soils at the USAFA J VTA indicated that the basic cadet training encampment activities and other training uses led to: increased bulk density and compaction, decreased infiltration rates, decreased vegetative biomass and litter, and decreased vegetative lifeform diversity. Research by Settergen and Cole (1970), Monti and Mackintosh (1979), and Trumbull et al. (1994) suggested that sites such as the basic cadet training sites - with low infiltration rates, increased runoff, reduced vegetation, and minimal litter layers - were susceptible to soil erosion. Trumbull et al.'s research (1994) on campsites indicated a loss of 28 to $61 \mathrm{~cm}$ of soil from recreational sites. Though actual erosion rates from the early-seral grasses/bare ground communities on the high and moderate use sites were not measured, USLE was used to estimate gross soil erosion rates (A) (Figure 11). Erosion rate for the low use plot (rate, 0.07 tons $^{-1} a^{-1}$ year ${ }^{-1}$ ) was 30 
times smaller than the erosion rate for the high use plot in the center of the basic cadet training encampment area (rate, 2 tons ha ${ }^{-1}$ year $^{-1}$ ). The erosion rate for the low use plot was between 6 and 7 times smaller than the erosion rates for the moderate use plot and the high use plot on the edge of the encampment area (rate, 0.5 and 0.4 tons ha $^{-1}$ year ${ }^{-1}$ respectively). Training activities appeared to have drastically increased soil erosion on the high and moderate use sites. As more soil and litter are eroded from the research area, more vegetation is lost, resulting in even more soil erosion. Soil erosion from the grassland sites in J VTA will degrade the plant and animal habitat and will diminish the water quality and aquatic habitat of Monument Creek. Therefore, some restoration efforts should be undertaken.

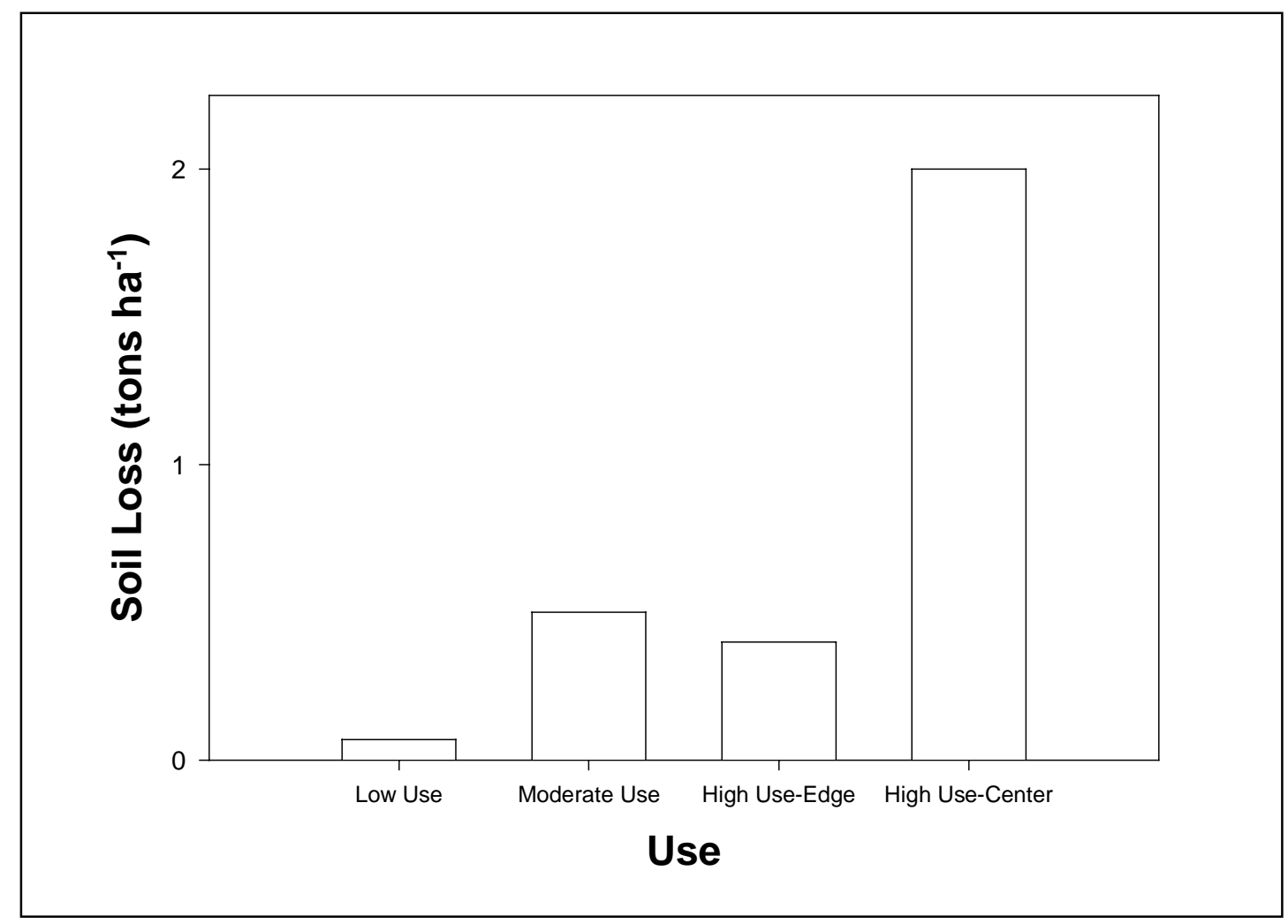

Figure 11. Comparison of Universal Soil Loss Equation modeled soil loss rates for grassland soils at the USAFA's JVTA based on intensity of use (high use site divided into two plots: a plot in the center of basic cadet training encampment area and one at the edge of encampment area).

\section{Management and Restoration}

Use of the research area for basic cadet training encampment is essential to the mission of the Academy. Continued use of the research area for basic cadet training encampment and other uses, however, will further degrade the soils and vegetation to such an extent that soil erosion will result. The research by Dr. McClendon's research team will produce additional information, recommendations, and a land management tool (the EDYS model), to assist in making sound 
land management decisions. Past research indicated that several management and restoration practices, if properly implemented, will minimize the impacts of the training use. These practices include, but are not limited to:

1. Significantly reducing or eliminating the other training uses.

2. Restricting training to roads, trails, and previously established areas. Past research, though not completely in agreement, seems to indicate that concentrating use to a few sites, when properly managed, is preferred over spreading out training use.

3. Implement comprehensive education and awareness programs.

4. Revegetation with native and resistant grasses should occur several meters outside of basic cadet training encampment area center. In the center, apply mulch to reduce soil erosion. Temporary fencing or planting of shrubs will reduce spread of trampling.

5. In compacted areas outside of the center of the basic cadet training encampment area, aerating the soil will help alleviate compaction, improve infiltration, decrease runoff, and thereby facilitate revegetation efforts. 


\section{Conclusion}

As stated earlier, DoD is increasingly aware of and becoming more proactive in regard to environmental management. In keeping with this environmental mission, this research has several implications for the USAFA's use of the JVTA. Three years of intensive use has caused significant impacts, which include increased bulk densities and compaction, decreased infiltration, and decreased plant biomass and litter. Continued use will likely cause increased soil erosion, which could diminish plant growth, damage animal and aquatic habitats, and decrease water quality. Therefore, management and restoration practices should be implemented, in conjunction with the USAFA-funded EDYS modeling effort, to minimize the impacts of this training use. 


\section{References}

Bayfield, N.G. 1973. Use and deterioration of some Scottish hill paths. J . Appl. Ecology. 10: 635-644.

Blake, G.R. and K.H. Hartge. 1986. Bulk Density. In A. Klute (ed.), Methods of Soil Analysis, Part I, Physical and Mineralogical Methods - Agronomy 9: 363-375, 2nd ed.

Bouwer, H. 1986. Intake rate: cylinder infiltrometer. In A. K lute (ed.), Methods of soil Analysis, Part I, Physical and Mineralogical Methods - Agronomy 9: 825-844, 2nd ed.

Bremner, J .M. and C.S. Mulvaney. 1986. Total nitrogen analysis. In A.L. Page (ed.), Methods of soil analysis, Part II. 2nd ed. Agronomy 9: 595-624.

Brown, J .H., J r., S.P. Kalisz, and W.R. Wright. 1977. Effects of recreational use on forested sites. Environ. Geology. 1: 425-431.

Childress, W.M., T. McClendon, and D.L. Price. 1999. A multi-scale ecological model for allocation of training activities on US Army installations, pp 80-108. In J effrey M. Klopatek and Robert H. Gardener (eds.), Landscape Ecological Analysis: Issues, Challenges, and I deas. Ecol. Stud. Series. Springer-Verlag, New York.

Cole, D.N. 1982. Wilderness campsite impacts: effect of amount of use. USDA For. Serv. Res. Pap. INT-284. I ntermtn. For. and Range Exp. Stn., Odgen, Utah. 34 pp.

Cole, D.N. 1986. Recreational impacts on backcountry campsites in Grand Canyon National Park, Arizona, USA. Environ. Mngt. 10: 651-659.

Cole, D.N. 1995a. Disturbance of natural vegetation by camping: experimental applications of low-level stress. Environ. Mngt. 19: 405-416.

Cole, D.N. 1995b. Recreational trampling experiments: effects of trampler weight and shoe type. USDA For. Serv. Res. Pap. INT-RN-425. Intermtn. Res. Stn., Odgen, Utah. 34 pp.

Dale, D. and T. Weaver. 1974. Trampling effects on vegetation of the trail corridors of north Rocky Mountain forests. J . Appl. Ecol. 11: 767-772.

Dawson, J .O., P.N. Hinz, and J .C. Gordon. 1974. Hiking-trail impact on I owa stream valley forest preserves. I owa StateJ . of Research. 48: 329-337.

Dawson, J .O., D.W. Countryman, and R.R. Fittin. 1978. Soil and vegetative patterns in northeastern I owa campgrounds. J . Soil Water Conserv. 33: 39-41. 
Deluca, T.H., W.A. Patterson, IV, W.A. Freimund, and D.N. Cole. 1998. Influence of Ilamas, horses, and hikers on soil erosion from established recreation trails in western Montana, USA. Environ. Mngt. 22: 255-262.

Dotzenko, A.D., N.T. Papamichos, and D.S. Romine. 1967. Effects of recreational use on soil and moisture conditions in Rocky Mountain National Park. J . Soil Water Conserv. 22: 196-197.

Dunn, B.A., B.G. Lockaby, and E.E. J ohnson. 1980. Camping and its relationship to forest soil and vegetation properties in South Carolina. For. Res. Series No. 34. Dept. of For., Clemson Univ., Clemson, S.C. 20p.

Dunn, B.A. 1984. Recreation effects on forest soil and vegetation: research synopsis and selected bibliography. Technical Paper No. 16. Dept. of For., Clemson Univ., Clemson, S.C.

Dunn, B.A. and W.D. Carroll. 1985. Floristic assessment of campsites in the Blue Ridge Region of South Carolina. For. Res. Series No. 40. Dept. of For., Clemson Univ., Clemson, S.C. 95p.

Dunne, T. and L.B. Leopold. 1996. Water in Environmental Planning. 14th ed. W.H. Freeman and Co., New York, NY.

ENSR Consulting and Engineering. 1997. Proposed environmental assessment, J ack's Valley operations, J ack's Valley Training Area, United States Air F orce Academy.

Foth, H.D. 1990. Fundamentals of Soil Science, 8th edition. J ohn Wiley and Sons, New York, NY.

Gee, G.W. and J.W. Bauder. 1986. Particle-size analysis. In A. Klute (ed.), Methods of Soil Analysis, Part I. Physical and Mineralogical Methods - Agronomy 9: 383-411, 2nd ed.

Geohring, L.D., A.J . Palazzo, R.W. Duell, and R.C. J ones. 1992. Drainage and soil compaction improvements to the US Military Academy Parade Field, pp 186-195. In Land Reclamation: Advances in Research and Technology. Proc. Int. Symp. ASAE, St. J œ, MI.

Hofmann, L. and R.E. Ries. 1991. Relationship of soil and plant characteristics to erosion and runoff on pasture and range. J. Soil Water Conserv. 46: 143-147.

Klute, A. 1986. Water retention: Iaboratory methods. In A. Klute (ed.), Methods of Soil Analysis, Part I. Physical and Mineral ogical Methods - Agronomy 9: 635-662, 2nd ed.

LaPage, W.F. 1962. Recreation and the forest site. J . For. 60: 319-321.

LaPage, W.F. 1967. Some observations on campground trampling and ground cover response. USDA For. Serv. Res. Paper NE-68, N ortheastern For. Exp. Stn., U pper Darby, PA. 11 p.

Larsen, L.S. 1981. Soil survey of the EI Paso County area. USDA-SCS and Col orado Ag. Exp. Stn. U.S. Gov. Print. Office, Washington, D.C.

Le Bissonnais, Y. and D. Arrouays. 1997. Aggregate stability and assessment of soil crustability and erodibility: II. application to humic loamy soils with various organic carbon contents. Eur. J. Soil Sci. 48: 39-48. 
Legg, M.H. and G. Schneider. 1977. Soil deterioration on campsites: northern forest types. Soil Sci. Soc. Am. J . 41: 437-441.

Lutz, H.J . 1945. Soil conditions on picnic grounds in public forest parks. J . For. 43:121-7.

McClendon, T. and W.M. Childress. 1997. Use of the EDYS simulation model to estimate training and ecological carrying capacity for J ack's Valley Training Area, Air Force Academy. University of Texas at EI Paso. Unpublished: Scope of Work submitted to theAir ForceAcademy.

Monti, P.W. and E.E. Mackintosh. 1979. Effect of camping on surface soil properties in the boreal forest region of Northwestern Ontario, Canada. Soil Sci. Soc. Am. J . 43: 1024-1029.

Monroe, J .S. and R. Wicander. 1992. Physical Geology: Exploring The Earth. West Publishing Company, St. Paul, MN.

Moore, R. 1992. Soil survey of the Pike National Forest, eastern part, Colorado: parts of Douglas, EI Paso, J efferson, and Teller Counties. USDA-SCS and Colorado Ag. Exp. Stn. U.S. Gov. Print. Office, Washington, D.C.

Morgan, R.P.C. 1985. The impact of recreation on mountain soils: towards a predictive model for soil erosion, pp112-131. In N.G. Bayfield and G.C. Barrow (eds.), Ecological impacts of outdoor recreation on mountain areas in Europe and North America. Restoration Ecology Research Group Report, Ashford, Kent, United Kingdom, No. 9.

Morgan, R.P.C. 1995. Soil Erosi on and Conservation. Longman Group Limited, Essex, England, and J ohn Wiley and Sons, New York, NY.

Nelson, D.Q. and L.E. Sommers. 1986. Total carbon, organic carbon, and organic matter. In A.L. Page, R.H. Miller, and D.R. Keeney (ed.), Methods of soil analysis. Part II. 2nd ed. Agronomy 9: 539-579.

Price, D.L., A.B. Anderson, P.J . Guertin, T. McClendon, and W.M. Childress. 1997. The U.S. Army's Land-Based Carrying Capacity. USACERL Technical Note 97/142. U.S. Army Construction Engineering Research Laboratory, Champaign, IL.

Pritchett, W.L. and R.F. Fisher. 1987. Properties and management of forest soils. J ohn Wiley and Sons, New York, New York.

Rauzi, F. and F.M. Smith. 1973. Infiltration rates: three soils with 3 grazing levels in northeastern Colorado. J . Range Mngt. 26: 126-129.

Ritter, D.F., R.C. Kochel, and J .R. Miller. 1995. The drainage basin. p.137-175. In Process Geomorphology. William C. Brown: Dubuque, IA.

Reed, A.H. 1983. The erosion risk of compaction. Soil Water. 11: 29-33.

Savabi, M.R. and G.F. Gifford. 1987. Application of selected soil loss equations to trampled soil conditions. Water Resour. Bulletin. 23: 709-716. 
Settergen, C.D. and D.M. Cole. 1970. Recreation effects on soil and vegetation in the Missouri Ozarks. J . For. 68: 231-233.

Sharratt, B., W. Voorhees, G. Mcl ntosh, and G. Lemme. 1998. Persistence of soil structural modifications along a historic wagon trail. Soil Sci. Soc. Am. J . 62: 774-777.

Soil Survey Staff. 1951. Soil survey manual. U.S. Gov. Print. Office, Washington, D.C.

Stewart, D.P.C., and K.C. Cameron. 1992. Effect of trampling on the soils of the St. J ames Walkway, New Zealand. J . Soil UseMngt. 8: 30-36.

Trumbull, V.L., P.C. Dubois, R.J . Brozka, and R. Guyette. 1994. Military camping impacts on vegetation and soils of the Ozark Plateau. J . Environ. Mngt. 40: 329-339.

U.S. Department of Agriculture (USDA). 1990. Official series description-Pring series. USDASCS. Http://www.statlab.iastate.edu/cgi-bin/osd/osdname.cgi.

USDA. 1991. Official series description-Tomah series. USDA-SCS. Http://www.statlab.iastate.edu/cgi-bin/osd/osdname.cgi.

USDA. 1994. EI Paso County (CO) field office technical guide. USDA-NRCS and Colorado Ag. Exp. Stn. U.S. Gov. Print. Office, Washington, D.C.

USDA. 1998. Infiltration methods. Agricultural Research Service, J ornada Range and Experimental Station, NM.

U.S. Department of the Interior (USDI). 1997. Integrated natural resources management plan and environmental assessment for the United States Air Force Academy. NPS D-315A-August 1997. Denver Service Center.

U.S. Environmental Protection Agency (USE PA). 1990. Handbook of methods for acid deposition studies. Laboratory analyses for soil chemistry: Sections 4, 5, 8, and 19. USEPA 600/490/023. Environmental Monitoring Systems Laboratory, Las Vegas, NV.

Wagar, J .A. 1964. The carrying capacity of wildlands for recreation. Soc. Am. For., For. Sci. Monog. 7. 23 pp.

Ward, R.M. and R.C. Berg. 1973. Soil compaction and recreation use. Prof. Geog. 25:369-372.

White, P.S. and S.T.A. Pickett. 1985. Natural disturbance and patch dynamics: an introduction, pp 3-13. In S.T.A. Pickett and P.S. White (ed.), The ecology of natural disturbance and patch dynamics. Academic Press, New York, NY.

Wischmeier, W.H. and D.D. Smith. 1960. A universal soil-loss equation to guide conservation farm planning. Trans. 7th Int. Congress of Soil Sci. Madison, WI. pp 418-425.

Yorks, T.P., N.E West, R.J . Mueller, and S.D. Warren. 1997. Toleration of traffic by vegetation: life form conclusions and summary extracts from a comprehensive data base. Environ. Mngt. 21: 121-131. 
Young, R.A. and A.R. Gilmore. 1976. Effects of various camping intensities on soil properties in Illinois campgrounds. Soil Sci. Soc. Am. J. 40: 908-911.

Young, R.A. 1978. Camping intensity effects on vegetative ground cover in Illinois campgrounds. J. Soil Water Conserv. 33: 36-39. 


\section{Appendix A: Bulk Density and Coarse Fragment Data}

\begin{tabular}{|c|c|c|c|c|c|}
\hline $\begin{array}{l}\text { Sample } \\
\text { Number }\end{array}$ & $\begin{array}{l}\text { Pre-Encampment } \\
\text { Bulk Density }\end{array}$ & $\begin{array}{l}\text { Post-Encampment } \\
\text { Bulk Density }\end{array}$ & $\begin{array}{c}\text { Coarse } \\
\text { Fragments }\end{array}$ & $\begin{array}{c}\text { Pre-Encampment } \\
\text { Adjusted Bulk Density }\end{array}$ & $\begin{array}{l}\text { Post-Encampment } \\
\text { Adjusted Bulk Density }\end{array}$ \\
\hline L1-1 & 0.96 & 1.26 & 18.31 & 0.87 & 1.19 \\
\hline L1-2 & 0.94 & 1.09 & 8.80 & 0.90 & 1.05 \\
\hline L1-3 & 0.82 & 1.19 & 8.84 & 0.77 & 1.16 \\
\hline L1-4 & 0.88 & 1.21 & 13.51 & 0.81 & 1.15 \\
\hline L1-5 & 1.01 & 1.09 & 13.02 & 0.95 & 1.04 \\
\hline L2-1 & 0.95 & 1.20 & 21.65 & 0.84 & 1.11 \\
\hline L2-2 & 1.15 & 1.25 & 17.85 & 1.08 & 1.18 \\
\hline L2-3 & 1.03 & 1.31 & 30.71 & 0.89 & 1.19 \\
\hline L2-4 & 1.16 & 1.31 & 26.62 & 1.04 & 1.21 \\
\hline L2-5 & 1.15 & 1.21 & 14.80 & 1.08 & 1.15 \\
\hline L3-1 & 0.97 & 1.07 & 8.11 & 0.93 & 1.03 \\
\hline L3-2 & 0.99 & 1.18 & 22.55 & 0.88 & 1.09 \\
\hline L3-3 & 1.02 & 1.12 & 15.41 & 0.95 & 1.05 \\
\hline L3-4 & 1.05 & 0.90 & 18.55 & 0.97 & 0.81 \\
\hline L3-5 & 1.05 & 1.13 & 12.46 & 0.99 & 1.08 \\
\hline L4-1 & 0.96 & 1.03 & 9.09 & 0.91 & 0.99 \\
\hline L4-2 & 1.01 & 1.11 & 18.58 & 0.92 & 1.03 \\
\hline L4-3 & 1.09 & 1.41 & 22.20 & 0.99 & 1.33 \\
\hline L4-4 & 1.11 & 0.95 & 15.66 & 1.05 & 0.87 \\
\hline L4-5 & 0.94 & 0.96 & 5.02 & 0.92 & 0.94 \\
\hline L5-1 & 1.14 & 1.15 & 23.97 & 1.04 & 1.05 \\
\hline L5-2 & 1.17 & 1.12 & 17.65 & 1.10 & 1.05 \\
\hline L5-3 & 1.12 & 1.02 & 13.68 & 1.06 & 0.95 \\
\hline L5-4 & 1.16 & 1.24 & 18.39 & 1.08 & 1.17 \\
\hline L5-5 & 1.14 & 1.31 & 18.35 & 1.07 & 1.24 \\
\hline M1-1 & 1.21 & 1.37 & 10.07 & 1.17 & 1.34 \\
\hline M1-2 & 1.38 & 1.37 & 5.20 & 1.37 & 1.35 \\
\hline M1-3 & 1.17 & 1.40 & 12.40 & 1.12 & 1.36 \\
\hline M1-4 & 1.25 & 1.29 & 11.59 & 1.21 & 1.24 \\
\hline M1-5 & 1.33 & 1.38 & 5.60 & 1.31 & 1.36 \\
\hline M2-1 & 1.51 & 1.41 & 20.69 & 1.44 & 1.33 \\
\hline M2-2 & 1.38 & 1.44 & 25.61 & 1.29 & 1.35 \\
\hline M2-3 & 1.33 & 1.45 & 16.78 & 1.26 & 1.40 \\
\hline M2-4 & 1.46 & 1.46 & 19.45 & 1.39 & 1.40 \\
\hline M2-5 & 1.38 & 1.50 & 27.05 & 1.28 & 1.41 \\
\hline
\end{tabular}


Bulk Density and Coarse Fragment Data (continued)

\begin{tabular}{|c|c|c|c|c|c|}
\hline $\begin{array}{l}\text { Sample } \\
\text { Number }\end{array}$ & $\begin{array}{l}\text { Pre-Encampment } \\
\text { Bulk Density }\end{array}$ & $\begin{array}{l}\text { Post-Encampment } \\
\text { Bulk Density }\end{array}$ & $\begin{array}{c}\text { Coarse } \\
\text { Fragments }\end{array}$ & $\begin{array}{l}\text { Pre-Encampment } \\
\text { Adjusted Bulk Density }\end{array}$ & $\begin{array}{l}\text { Post-Encampment } \\
\text { Adjusted Bulk Density }\end{array}$ \\
\hline M3-1 & 1.30 & 1.49 & 13.50 & 1.25 & 1.44 \\
\hline M3-2 & 1.30 & 1.37 & 19.70 & 1.22 & 1.30 \\
\hline M3-3 & 1.20 & 1.47 & 23.06 & 1.11 & 1.39 \\
\hline M3-4 & 1.33 & 1.31 & 16.22 & 1.27 & 1.25 \\
\hline M3-5 & 1.30 & 1.28 & 12.19 & 1.25 & 1.23 \\
\hline M5-1 & 1.14 & 1.42 & 19.35 & 1.05 & 1.35 \\
\hline M5-2 & 1.37 & 1.40 & 25.00 & 1.28 & 1.31 \\
\hline M5-3 & 1.34 & 1.58 & 36.56 & 1.20 & 1.47 \\
\hline M5-4 & 1.31 & 1.56 & 33.15 & 1.18 & 1.46 \\
\hline M5-5 & 1.40 & 1.56 & 34.31 & 1.27 & 1.45 \\
\hline $\mathrm{H} 1-1$ & 1.16 & 1.37 & 16.11 & 1.09 & 1.31 \\
\hline $\mathrm{H} 1-2$ & 1.21 & 1.38 & 16.40 & 1.15 & 1.33 \\
\hline $\mathrm{H} 1-3$ & 1.22 & 1.36 & 14.53 & 1.16 & 1.31 \\
\hline $\mathrm{H} 1-4$ & 1.27 & 1.39 & 19.76 & 1.19 & 1.31 \\
\hline $\mathrm{H} 1-5$ & 1.28 & 1.40 & 12.90 & 1.23 & 1.35 \\
\hline $\mathrm{H} 2-1$ & 1.23 & 1.46 & 22.62 & 1.14 & 1.39 \\
\hline $\mathrm{H} 2-2$ & 1.37 & 1.36 & 21.76 & 1.29 & 1.28 \\
\hline $\mathrm{H} 2-3$ & 1.18 & 1.50 & 41.60 & 1.00 & 1.35 \\
\hline $\mathrm{H} 2-4$ & 1.76 & 1.60 & 43.01 & 1.64 & 1.46 \\
\hline $\mathrm{H} 2-5$ & 1.73 & 1.57 & 37.12 & 1.63 & 1.45 \\
\hline $\mathrm{H} 3-1$ & 1.33 & 1.62 & 91.86 & 0.90 & 1.28 \\
\hline $\mathrm{H} 3-2$ & 1.47 & 1.57 & 96.51 & 1.05 & 1.20 \\
\hline H3-3 & 1.54 & 1.84 & 136.41 & 0.89 & 1.37 \\
\hline $\mathrm{H} 3-4$ & 1.53 & 1.46 & 63.54 & 1.29 & 1.21 \\
\hline H3-5 & 1.58 & 1.41 & 90.02 & 1.23 & 1.01 \\
\hline $\mathrm{H} 4-1$ & 1.31 & 1.39 & 17.05 & 1.24 & 1.33 \\
\hline $\mathrm{H} 4-2$ & 1.36 & 1.42 & 23.97 & 1.27 & 1.33 \\
\hline $\mathrm{H} 4-3$ & 1.29 & 1.42 & 18.64 & 1.21 & 1.35 \\
\hline $\mathrm{H} 4-4$ & 1.40 & 1.36 & 14.03 & 1.35 & 1.31 \\
\hline $\mathrm{H} 4-5$ & 1.41 & 1.46 & 16.99 & 1.35 & 1.40 \\
\hline H5-1 & 1.26 & 1.32 & 12.03 & 1.21 & 1.28 \\
\hline H5-2 & 1.42 & 1.52 & 26.06 & 1.32 & 1.43 \\
\hline $\mathrm{H} 5-3$ & 1.29 & 1.32 & 9.31 & 1.26 & 1.29 \\
\hline $\mathrm{H} 5-4$ & 1.35 & 1.42 & 14.70 & 1.30 & 1.37 \\
\hline H5-5 & 1.41 & 1.47 & 23.31 & 1.32 & 1.39 \\
\hline
\end{tabular}




\section{Appendix B: Infiltration Rate Data}

\begin{tabular}{|c|c|c|}
\hline Site & Rate (cm/min) & Site Mean \\
\hline L1 & 2.71 & \\
\hline L2 & 3.14 & \\
\hline L3 & 3.93 & \\
\hline L4 & 5.45 & \\
\hline L5 & 3.90 & 3.83 \\
\hline M1 & 0.68 & \\
\hline M2 & 0.57 & \\
\hline M3 & 0.61 & \\
\hline M4 & 0.76 & \\
\hline M5 & 0.73 & 0.67 \\
\hline H1 & 0.41 & \\
\hline H2 & 0.65 & \\
\hline H3 & 1.00 & \\
\hline H4 & 0.55 & \\
\hline H5 & 0.53 & 0.63 \\
\hline
\end{tabular}




\section{Appendix C: Particle Size Analysis Results}

\begin{tabular}{|c|c|c|c|c|c|c|c|c|c|c|c|c|}
\hline Plot & Depth & Texture & Sand & Silt & Clay & $\begin{array}{l}\text { Very } \\
\text { Coarse } \\
\text { Sand }\end{array}$ & $\begin{array}{l}\text { Coarse } \\
\text { Sand }\end{array}$ & $\begin{array}{c}\text { Medium } \\
\text { Sand }\end{array}$ & $\begin{array}{l}\text { Fine } \\
\text { Sand }\end{array}$ & $\begin{array}{l}\text { Very } \\
\text { Fine } \\
\text { Sand }\end{array}$ & $\begin{array}{c}\text { Coarse } \\
\text { Silt }\end{array}$ & $\begin{array}{c}\text { Fine } \\
\text { Silt }\end{array}$ \\
\hline & $\mathbf{c m}$ & & $---\cdot$ & 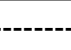 & - & - & --------- & \%-------.-. & --------. & ---- & 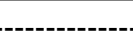 & --- \\
\hline \multirow[t]{3}{*}{ L1 } & $0-5$ & $\begin{array}{l}\text { Sandy } \\
\text { Loam }\end{array}$ & 64 & 28 & 8 & 11 & 10 & 11 & 19 & 13 & 16 & 12 \\
\hline & $5-10$ & $\begin{array}{l}\text { Sandy } \\
\text { Loam }\end{array}$ & 63 & 27 & 10 & 11 & 9 & 12 & 19 & 13 & 14 & 13 \\
\hline & $10-20$ & $\begin{array}{l}\text { Sandy } \\
\text { Loam }\end{array}$ & 62 & 28 & 10 & 7 & 7 & 13 & 20 & 15 & 12 & 16 \\
\hline \multirow[t]{3}{*}{ L2 } & $0-5$ & $\begin{array}{l}\text { Sandy } \\
\text { Loam }\end{array}$ & 60 & 30 & 10 & 6 & 7 & 12 & 20 & 15 & 12 & 18 \\
\hline & $5-10$ & $\begin{array}{l}\text { Sandy } \\
\text { Loam }\end{array}$ & 56 & 34 & 10 & 6 & 6 & 10 & 19 & 14 & 20 & 14 \\
\hline & $10-20$ & $\begin{array}{l}\text { Sandy } \\
\text { Loam }\end{array}$ & 60 & 30 & 10 & 6 & 6 & 12 & 20 & 16 & 14 & 16 \\
\hline \multirow[t]{3}{*}{ L3 } & $0-5$ & $\begin{array}{l}\text { Sandy } \\
\text { Loam }\end{array}$ & 63 & 30 & 7 & 10 & 11 & 13 & 16 & 12 & 14 & 16 \\
\hline & $5-10$ & $\begin{array}{l}\text { Sandy } \\
\text { Loam }\end{array}$ & 64 & 29 & 7 & 12 & 11 & 13 & 16 & 12 & 15 & 14 \\
\hline & $10-20$ & $\begin{array}{l}\text { Sandy } \\
\text { Loam }\end{array}$ & 64 & 29 & 7 & 12 & 12 & 13 & 16 & 12 & 15 & 14 \\
\hline \multirow[t]{3}{*}{ L4 } & $0-5$ & $\begin{array}{l}\text { Loamy } \\
\text { Coarse } \\
\text { Sand }\end{array}$ & 73 & 24 & 3 & 12 & 15 & 16 & 18 & 11 & 13 & 11 \\
\hline & $5-10$ & $\begin{array}{l}\text { Coarse } \\
\text { Sandy } \\
\text { Loam }\end{array}$ & 73 & 23 & 4 & 13 & 14 & 15 & 19 & 12 & 13 & 10 \\
\hline & $10-20$ & $\begin{array}{l}\text { Loamy } \\
\text { Coarse } \\
\text { Sand }\end{array}$ & 77 & 19 & 4 & 14 & 14 & 17 & 19 & 12 & 10 & 9 \\
\hline \multirow[t]{3}{*}{ L5 } & $0-5$ & $\begin{array}{l}\text { Loamy } \\
\text { Coarse } \\
\text { Sand }\end{array}$ & 76 & 20 & 4 & 11 & 15 & 18 & 20 & 11 & 12 & 8 \\
\hline & $5-10$ & $\begin{array}{l}\text { Loamy } \\
\text { Coarse } \\
\text { Sand }\end{array}$ & 77 & 19 & 4 & 14 & 15 & 18 & 20 & 11 & 11 & 8 \\
\hline & $10-20$ & $\begin{array}{l}\text { Loamy } \\
\text { Coarse } \\
\text { Sand }\end{array}$ & 78 & 18 & 4 & 17 & 15 & 18 & 19 & 10 & 10 & 8 \\
\hline
\end{tabular}


Particle Size Analysis Results (continued)

\begin{tabular}{|c|c|c|c|c|c|c|c|c|c|c|c|c|}
\hline Plot & Depth & Texture & Sand & Silt & Clay & $\begin{array}{c}\text { Very } \\
\text { Coarse } \\
\text { Sand }\end{array}$ & $\begin{array}{c}\text { Coarse } \\
\text { Sand }\end{array}$ & $\begin{array}{l}\text { Medium } \\
\text { Sand }\end{array}$ & $\begin{array}{l}\text { Fine } \\
\text { Sand }\end{array}$ & $\begin{array}{l}\text { Very } \\
\text { Fine } \\
\text { Sand }\end{array}$ & $\begin{array}{c}\text { Coarse } \\
\text { Silt }\end{array}$ & $\begin{array}{c}\text { Fine } \\
\text { Silt }\end{array}$ \\
\hline & $\mathbf{c m}$ & & & & & & 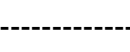 & ---\%---. & --- & --- & ------------ & \\
\hline \multirow[t]{3}{*}{ M1 } & $0-5$ & $\begin{array}{l}\text { Fine } \\
\text { Sandy } \\
\text { Loam }\end{array}$ & 67 & 27 & 6 & 7 & 9 & 14 & 24 & 14 & 14 & 13 \\
\hline & $5-10$ & $\begin{array}{l}\text { Fine } \\
\text { Sandy } \\
\text { Loam }\end{array}$ & 69 & 26 & 5 & 6 & 8 & 15 & 27 & 14 & 13 & 13 \\
\hline & $10-20$ & $\begin{array}{l}\text { Fine } \\
\text { Sandy } \\
\text { Loam }\end{array}$ & 70 & 24 & 6 & 5 & 7 & 15 & 28 & 15 & 12 & 12 \\
\hline \multirow[t]{3}{*}{ M2 } & $0-5$ & $\begin{array}{l}\text { Loamy } \\
\text { Sand }\end{array}$ & 75 & 21 & 4 & 11 & 12 & 18 & 23 & 12 & 11 & 10 \\
\hline & $5-10$ & $\begin{array}{l}\text { Loamy } \\
\text { Sand }\end{array}$ & 75 & 21 & 4 & 11 & 11 & 17 & 24 & 12 & 12 & 9 \\
\hline & $10-20$ & $\begin{array}{l}\text { Loamy } \\
\text { Sand }\end{array}$ & 77 & 19 & 4 & 11 & 11 & 18 & 25 & 12 & 11 & 8 \\
\hline \multirow[t]{3}{*}{ M3 } & $0-5$ & $\begin{array}{l}\text { Sandy } \\
\text { Loam }\end{array}$ & 74 & 19 & 7 & 8 & 10 & 19 & 25 & 13 & 10 & 9 \\
\hline & $5-10$ & $\begin{array}{l}\text { Sandy } \\
\text { Loam }\end{array}$ & 74 & 19 & 7 & 9 & 11 & 18 & 24 & 12 & 11 & 8 \\
\hline & $10-20$ & $\begin{array}{l}\text { Sandy } \\
\text { Loam }\end{array}$ & 72 & 21 & 7 & 7 & 10 & 17 & 25 & 13 & 11 & 10 \\
\hline \multirow[t]{3}{*}{ M4 } & $0-5$ & $\begin{array}{l}\text { Sandy } \\
\text { Loam }\end{array}$ & 66 & 25 & 9 & 7 & 8 & 17 & 23 & 12 & 14 & 11 \\
\hline & $5-10$ & $\begin{array}{l}\text { Sandy } \\
\text { Loam }\end{array}$ & 67 & 25 & 8 & 7 & 8 & 16 & 23 & 13 & 13 & 12 \\
\hline & $10-20$ & $\begin{array}{l}\text { Sandy } \\
\text { Loam }\end{array}$ & 69 & 23 & 8 & 8 & 8 & 17 & 23 & 13 & 12 & 11 \\
\hline \multirow[t]{3}{*}{ M5 } & $0-5$ & $\begin{array}{l}\text { Coarse } \\
\text { Sandy } \\
\text { Loam }\end{array}$ & 75 & 19 & 6 & 13 & 16 & 17 & 19 & 9 & 10 & 9 \\
\hline & $5-10$ & $\begin{array}{l}\text { Loamy } \\
\text { Coarse } \\
\text { Sand }\end{array}$ & 79 & 16 & 5 & 17 & 17 & 19 & 18 & 8 & 8 & 8 \\
\hline & $10-20$ & $\begin{array}{l}\text { Loamy } \\
\text { Coarse } \\
\text { Sand }\end{array}$ & 80 & 15 & 5 & 20 & 17 & 18 & 18 & 8 & 8 & 7 \\
\hline
\end{tabular}


Particle Size Analysis Results (continued)

\begin{tabular}{|c|c|c|c|c|c|c|c|c|c|c|c|c|}
\hline Plot & Depth & Texture & Sand & Silt & Clay & $\begin{array}{c}\text { Very } \\
\text { Coarse } \\
\text { Sand }\end{array}$ & $\begin{array}{c}\text { Coarse } \\
\text { Sand }\end{array}$ & $\begin{array}{c}\text { Medium } \\
\text { Sand }\end{array}$ & $\begin{array}{l}\text { Fine } \\
\text { Sand }\end{array}$ & $\begin{array}{l}\text { Very } \\
\text { Fine } \\
\text { Sand }\end{array}$ & $\begin{array}{c}\text { Coarse } \\
\text { Silt }\end{array}$ & $\begin{array}{c}\text { Fine } \\
\text { Silt }\end{array}$ \\
\hline & $\mathrm{cm}$ & & & & & & & $\%$ & 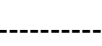 & ---- & -- & ---- \\
\hline \multirow[t]{3}{*}{$\mathrm{H} 1$} & $0-5$ & $\begin{array}{l}\text { Sandy } \\
\text { Loam }\end{array}$ & 61 & 31 & 8 & 8 & 10 & 14 & 18 & 11 & 14 & 17 \\
\hline & $5-10$ & $\begin{array}{l}\text { Sandy } \\
\text { Loam }\end{array}$ & 62 & 30 & 8 & 10 & 9 & 14 & 18 & 11 & 14 & 16 \\
\hline & $10-20$ & $\begin{array}{l}\text { Sandy } \\
\text { Loam }\end{array}$ & 67 & 26 & 7 & 9 & 10 & 15 & 21 & 12 & 13 & 13 \\
\hline \multirow[t]{3}{*}{$\mathrm{H} 2$} & $0-5$ & $\begin{array}{c}\text { Coarse } \\
\text { Sandy } \\
\text { Loam }\end{array}$ & 72 & 22 & 6 & 15 & 15 & 17 & 16 & 9 & 11 & 11 \\
\hline & $5-10$ & $\begin{array}{l}\text { Coarse } \\
\text { Sandy } \\
\text { Loam }\end{array}$ & 72 & 22 & 6 & 16 & 15 & 16 & 16 & 9 & 11 & 11 \\
\hline & $10-20$ & $\begin{array}{l}\text { Loamy } \\
\text { Coarse } \\
\text { Sand }\end{array}$ & 77 & 18 & 5 & 20 & 16 & 17 & 16 & 8 & 8 & 10 \\
\hline \multirow[t]{3}{*}{$\mathrm{H} 3$} & $0-5$ & $\begin{array}{l}\text { Loamy } \\
\text { Coarse } \\
\text { Sand }\end{array}$ & 80 & 12 & 8 & 23 & 19 & 18 & 15 & 7 & 5 & 7 \\
\hline & $5-10$ & $\begin{array}{l}\text { Coarse } \\
\text { Sandy } \\
\text { Loam }\end{array}$ & 71 & 20 & 9 & 15 & 15 & 16 & 17 & 9 & 9 & 11 \\
\hline & $10-20$ & $\begin{array}{l}\text { Coarse } \\
\text { Sandy } \\
\text { Loam }\end{array}$ & 71 & 23 & 6 & 14 & 13 & 16 & 18 & 9 & 12 & 11 \\
\hline \multirow[t]{3}{*}{$\mathrm{H} 4$} & $0-5$ & $\begin{array}{l}\text { Sandy } \\
\text { Loam }\end{array}$ & 69 & 25 & 6 & 8 & 12 & 17 & 20 & 12 & 11 & 14 \\
\hline & $5-10$ & $\begin{array}{l}\text { Sandy } \\
\text { Loam }\end{array}$ & 70 & 24 & 6 & 9 & 12 & 16 & 20 & 12 & 12 & 12 \\
\hline & $10-20$ & $\begin{array}{l}\text { Sandy } \\
\text { Loam }\end{array}$ & 71 & 23 & 6 & 10 & 13 & 16 & 20 & 12 & 11 & 12 \\
\hline \multirow[t]{3}{*}{$\mathrm{H} 5$} & $0-5$ & $\begin{array}{l}\text { Sandy } \\
\text { Loam }\end{array}$ & 68 & 26 & 6 & 9 & 13 & 15 & 19 & 11 & 13 & 13 \\
\hline & $5-10$ & $\begin{array}{l}\text { Sandy } \\
\text { Loam }\end{array}$ & 70 & 24 & 6 & 11 & 12 & 17 & 19 & 11 & 11 & 13 \\
\hline & $10-20$ & $\begin{array}{l}\text { Sandy } \\
\text { Loam }\end{array}$ & 71 & 23 & 6 & 11 & 13 & 18 & 18 & 11 & 11 & 12 \\
\hline
\end{tabular}




\section{Appendix D: Soil Water Holding Capacity Data}

\begin{tabular}{|c|c|c|c|}
\hline $\begin{array}{l}\text { Sample } \\
\text { Number }\end{array}$ & $\begin{array}{c}\text { Gravimetric } \\
\text { Water Content } \\
\text { at } 0.10 \mathrm{Bar}\end{array}$ & $\begin{array}{c}\text { Gravimetric } \\
\text { Water Content } \\
\text { at } 0.33 \mathrm{Bar} \\
\end{array}$ & $\begin{array}{c}\text { Gravimetric } \\
\text { Water Content } \\
\text { at } 15 \text { Bars } \\
\end{array}$ \\
\hline L1-1A & 0.20 & 0.12 & 0.06 \\
\hline L1-2A & 0.21 & 0.12 & 0.06 \\
\hline L2-1A & 0.18 & 0.12 & 0.05 \\
\hline L2-2A & 0.20 & 0.11 & 0.05 \\
\hline L3-1A & 0.20 & 0.12 & 0.05 \\
\hline L3-2A & 0.22 & 0.11 & 0.06 \\
\hline L4-1A & 0.15 & 0.08 & 0.06 \\
\hline L4-2A & 0.19 & 0.10 & 0.05 \\
\hline L5-1A & 0.15 & 0.06 & 0.04 \\
\hline L5-2A & 0.13 & 0.07 & 0.04 \\
\hline $\mathrm{M} 1-1 \mathrm{~A}$ & 0.21 & 0.11 & 0.06 \\
\hline M1-2A & 0.18 & 0.09 & 0.04 \\
\hline$M 2-1 A$ & 0.18 & 0.09 & 0.05 \\
\hline M2-2A & 0.18 & 0.09 & 0.05 \\
\hline M3-1A & 0.15 & 0.08 & 0.09 \\
\hline M3-2A & 0.14 & 0.09 & 0.04 \\
\hline $\mathrm{M} 4-1 \mathrm{~A}$ & 0.22 & 0.14 & 0.05 \\
\hline M4-2A & 0.26 & 0.11 & 0.05 \\
\hline M5-1A & 0.15 & 0.08 & 0.05 \\
\hline M5-2A & 0.19 & 0.07 & 0.03 \\
\hline $\mathrm{H} 1-1 \mathrm{~A}$ & 0.24 & 0.15 & 0.08 \\
\hline $\mathrm{H} 1-2 \mathrm{~A}$ & 0.22 & 0.13 & 0.05 \\
\hline $\mathrm{H} 2-1 \mathrm{~A}$ & 0.13 & 0.09 & 0.04 \\
\hline $\mathrm{H} 2-2 \mathrm{~A}$ & 0.15 & 0.08 & 0.04 \\
\hline H3-1A & 0.12 & 0.04 & 0.03 \\
\hline H3-2A & 0.08 & 0.05 & 0.03 \\
\hline $\mathrm{H} 4-1 \mathrm{~A}$ & 0.20 & 0.11 & 0.06 \\
\hline $\mathrm{H} 4-2 \mathrm{~A}$ & 0.21 & 0.10 & 0.04 \\
\hline $\mathrm{H} 5-1 \mathrm{~A}$ & 0.19 & 0.10 & 0.04 \\
\hline $\mathrm{H} 5-2 \mathrm{~A}$ & 0.15 & 0.10 & 0.05 \\
\hline
\end{tabular}




\section{Appendix E: Total Carbon and Nitrogen Concentration Analysis Results}

\begin{tabular}{|c|c|c|c|c|}
\hline Plot & Depth (cm) & Carbon $\left(\mathrm{g} \mathrm{kg}^{-1}\right)$ & Nitrogen $\left(\mathrm{g} \mathrm{kg}^{-1}\right)$ & $\mathrm{C}: \mathrm{N}\left(\mathrm{mol} \mathrm{mol}^{-1}\right)$ \\
\hline L1 & $0-5$ & 2.154 & 0.153 & 16.42 \\
\hline L1 & $5-10$ & 1.301 & 0.105 & 14.46 \\
\hline L1 & $10-20$ & 0.982 & 0.078 & 14.69 \\
\hline L2 & $0-5$ & 1.460 & 0.121 & 14.08 \\
\hline L2 & $5-10$ & 0.980 & 0.078 & 14.66 \\
\hline L2 & $10-20$ & 0.889 & 0.067 & 15.48 \\
\hline L3 & $0-5$ & 1.927 & 0.139 & 16.17 \\
\hline L3 & $5-10$ & 1.301 & 0.098 & 15.49 \\
\hline L3 & $10-20$ & 1.136 & 0.078 & 16.99 \\
\hline L4 & $0-5$ & 2.229 & 0.149 & 17.45 \\
\hline L4 & $5-10$ & 1.348 & 0.090 & 17.47 \\
\hline L4 & $10-20$ & 0.905 & 0.055 & 19.20 \\
\hline L5 & $0-5$ & 1.425 & 0.087 & 19.11 \\
\hline L5 & $5-10$ & 0.943 & 0.072 & 15.28 \\
\hline L5 & $10-20$ & 0.732 & 0.054 & 15.95 \\
\hline M1 & $0-5$ & 2.108 & 0.150 & 16.40 \\
\hline M1 & $5-10$ & 1.178 & 0.095 & 14.47 \\
\hline M1 & $10-20$ & 0.704 & 0.066 & 12.44 \\
\hline $\mathrm{M} 2$ & $0-5$ & 1.521 & 0.125 & 14.20 \\
\hline M2 & $5-10$ & 1.089 & 0.103 & 12.33 \\
\hline M2 & $10-20$ & 0.623 & 0.059 & 12.32 \\
\hline M3 & $0-5$ & 1.440 & 0.122 & 13.77 \\
\hline M3 & $5-10$ & 0.828 & 0.077 & 12.55 \\
\hline M3 & $10-20$ & 0.653 & 0.061 & 12.49 \\
\hline M4 & $0-5$ & 2.189 & 0.180 & 14.19 \\
\hline M4 & 5-10 & 1.119 & 0.111 & 11.76 \\
\hline M4 & $10-20$ & 0.923 & 0.093 & 11.58 \\
\hline M5 & $0-5$ & 1.732 & 0.131 & 15.42 \\
\hline M5 & $5-10$ & 0.777 & 0.073 & 12.42 \\
\hline M5 & $10-20$ & 0.883 & 0.077 & 13.38 \\
\hline $\mathrm{H} 1$ & $0-5$ & 2.301 & 0.175 & 15.34 \\
\hline $\mathrm{H} 1$ & $5-10$ & 1.504 & 0.118 & 14.87 \\
\hline $\mathrm{H} 1$ & $10-20$ & 0.714 & 0.059 & 14.12 \\
\hline $\mathrm{H} 2$ & $0-5$ & 1.846 & 0.129 & 16.76 \\
\hline $\mathrm{H} 2$ & $5-10$ & 0.730 & 0.061 & 13.96 \\
\hline $\mathrm{H} 2$ & $10-20$ & 0.537 & 0.047 & 13.33 \\
\hline $\mathrm{H} 3$ & $0-5$ & 1.088 & 0.071 & 17.88 \\
\hline $\mathrm{H} 3$ & $5-10$ & 1.787 & 0.134 & 15.56 \\
\hline H3 & $10-20$ & 0.925 & 0.073 & 14.78 \\
\hline $\mathrm{H} 4$ & $0-5$ & 1.643 & 0.128 & 14.98 \\
\hline $\mathrm{H} 4$ & $5-10$ & 1.240 & 0.094 & 15.39 \\
\hline $\mathrm{H} 4$ & $10-20$ & 0.607 & 0.044 & 16.09 \\
\hline H5 & $0-5$ & 1.720 & 0.119 & 16.86 \\
\hline H5 & $5-10$ & 0.972 & 0.072 & 15.75 \\
\hline $\mathrm{H} 5$ & $10-20$ & 0.576 & 0.041 & 16.39 \\
\hline
\end{tabular}




\section{Appendix F: Total Aboveground Biomass and Litter Results}

\begin{tabular}{|c|c|c|}
\hline \multicolumn{3}{|c|}{ Low Use Plot } \\
\hline Species & $\begin{array}{c}\text { Dry Mass } \\
\left(\mathrm{g} \mathrm{m}^{-2}\right)\end{array}$ & $\begin{array}{c}\% \text { Relative } \\
\text { Biomass }\end{array}$ \\
\hline Stipa comata & 47.4 & 35.3 \\
\hline Artemisia frigida & 35.74 & 26.7 \\
\hline Sporobolus asper & 14.3 & 10.7 \\
\hline Carex rossii & 10.1 & 7.5 \\
\hline Bouteloua gracilis & 8.6 & 6.4 \\
\hline Eriogonum annuum & 2.8 & 2.1 \\
\hline Bromus tectorum & 2.1 & 1.5 \\
\hline Verbascum thapsus & 1.9 & 1.4 \\
\hline Tradescantia occidentalis & 1.9 & 1.4 \\
\hline Sitanion hystrix & 1.7 & 1.3 \\
\hline Poa pratensis & 1.7 & 1.3 \\
\hline Linaria dalmatica & 1.3 & 1.0 \\
\hline Koeleria macrantha & 1.1 & 0.8 \\
\hline Bromus japonicus & 1.1 & 0.8 \\
\hline Senecio fendleri & 0.6 & 0.5 \\
\hline Dalea purpurea & 0.4 & 0.3 \\
\hline Gaura coccinea & 0.4 & 0.3 \\
\hline Cryptantha sp. & 0.3 & 0.2 \\
\hline Agropyron smithii & 0.3 & 0.2 \\
\hline Conyza canadensis & 0.3 & 0.2 \\
\hline Sporobolus cryptandrus & 0.3 & 0.1 \\
\hline Total aboveground biomass & 134.1 & \\
\hline Biomass-Grasses & 78.5 & \\
\hline Biomass-Forbs/Sedges & 55.6 & \\
\hline Litter & 103.8 & \\
\hline
\end{tabular}




\section{Moderate Use Plot}

\begin{tabular}{lcc}
\hline \multicolumn{1}{c}{ Species } & $\begin{array}{c}\text { Dry Mass } \\
\left(\mathbf{g ~ m}^{-2}\right)\end{array}$ & $\begin{array}{c}\text { \% Relative } \\
\text { Biomass }\end{array}$ \\
\hline Koeleria macranths & 35.2 & 43.7 \\
Stipa comata & 19.6 & 24.3 \\
Carex rossii & 5.6 & 6.9 \\
Bouteloua gracilis & 4.2 & 5.2 \\
Sporobolus asper & 3.5 & 4.3 \\
Agropyron smithii & 3.4 & 4.2 \\
Rosa woodsii & 1.5 & 1.9 \\
Thelosperma megapotamicum & 1.2 & 1.5 \\
Heterotheca villosa & 1.1 & 1.4 \\
Artemisia frigida & 0.9 & 1.2 \\
Oenothera albicaulis & 0.9 & 1.1 \\
Dalea purpurea & 0.7 & 0.9 \\
Linaria dalmatica & 0.6 & 0.7 \\
Lesquerella montana & 0.5 & 0.6 \\
Tradescantia occidentalis & 0.4 & 0.5 \\
Tragopogon dubius & 0.4 & 0.5 \\
Lithospermum incisum & 0.4 & 0.5 \\
Liatris punctata & 0.4 & 0.5 \\
Plantago patagonica & 0.1 & 0.1 \\
\hline Total aboveground biomass & 80.7 & \\
\hline Biomass-Grasses & 65.9 & \\
Biomass-Forbs/Sedges & 13.3 & \\
Biomass-Shrubs & 1.5 & \\
Litter . & 27.2 & \\
& &
\end{tabular}

High Use Plot-Center of Encampment

\begin{tabular}{lcc}
\hline \multicolumn{1}{c}{ Species } & $\begin{array}{c}\text { Dry Mass } \\
\left(\mathbf{g ~ m}^{-2}\right)\end{array}$ & $\begin{array}{c}\text { \% Relative } \\
\text { Biomass }\end{array}$ \\
\hline Bromus tectorum & 13.6 & 32.1 \\
Erodium cicutarium & 6.8 & 16.1 \\
Poa pratensis & 6.7 & 15.8 \\
Sitanion hystrix & 4.9 & 11.6 \\
Sporobolus cryptandrus & 3.1 & 7.4 \\
Carex rossii & 1.1 & 2.6 \\
Plantago patagonica & 1.0 & 2.4 \\
Dalea purpurea & 0.9 & 2.1 \\
Cryptantha virgata & 0.9 & 2.0 \\
Bouteloua gracilis & 0.8 & 1.9 \\
Koeleria macrantha & 0.7 & 1.7 \\
Conyza canadensis & 0.6 & 1.3 \\
Linaria dalmatica & 0.4 & 1.0 \\
Agropyron smithii & 0.3 & 0.7 \\
Vulpia octoflora & 0.2 & 0.5 \\
Taraxacum officinale & 0.1 & 0.3 \\
Antennaria parvifolia & 0.1 & 0.3 \\
Linum sp. & 0.1 & 0.1 \\
\hline Total aboveground biomass & 42.4 & \\
\hline Biomass-Grasses & 30.4 & \\
Biomass-Forbs/Sedges & 12.0 & \\
Litter & 9.7 &
\end{tabular}


High Use Plot-Edge of Encampment

\begin{tabular}{|c|c|c|}
\hline Species & $\begin{array}{c}\text { Dry Mass } \\
\left(\mathrm{g} \mathrm{m}^{-2}\right)\end{array}$ & $\begin{array}{c}\text { \% Relative } \\
\text { Biomass }\end{array}$ \\
\hline Stipa comata & 17.9 & 22.9 \\
\hline Sporobolus asper & 10.5 & 13.4 \\
\hline Linaria dalmatica & 8.6 & 11.0 \\
\hline Poa pratensis & 8.4 & 10.8 \\
\hline Carex rossii & 7.3 & 9.3 \\
\hline Bromus tectorum & 4.7 & 6.0 \\
\hline Koeleria macrantha & 3.8 & 4.8 \\
\hline Bouteloua gracilis & 3.3 & 4.2 \\
\hline Artemisia frigida & 2.7 & 3.4 \\
\hline Andropogon gerardii & 2.3 & 3.0 \\
\hline Heterotheca villosa & 2.2 & 2.8 \\
\hline Dalea purpurea & 1.5 & 2.0 \\
\hline Vulpia octoflora & 1.2 & 1.5 \\
\hline Verbena bracteata & 1.1 & 1.4 \\
\hline Plantago patagonica & 0.9 & 1.1 \\
\hline Lithospermum incisum & 0.6 & 0.7 \\
\hline Erodium cicutarium & 0.3 & 0.4 \\
\hline Sporobolus cryptandrus & 0.3 & 0.3 \\
\hline Verbascum thapsus & 0.2 & 0.3 \\
\hline Taraxacum officinale & 0.2 & 0.3 \\
\hline Castilleja linearifolia & 0.1 & 0.2 \\
\hline Arenaria fendleri & 0.1 & 0.1 \\
\hline Unknown 7 & 0.1 & 0.1 \\
\hline Eriogonum annuum & 0.1 & 0.1 \\
\hline Cryptantha virgata & 0.1 & 0.1 \\
\hline Total aboveground biomass & 78.4 & \\
\hline Biomass-Grasses & 52.4 & \\
\hline Biomass-Forbs/Sedges & 26.0 & \\
\hline Litter & 26.2 & \\
\hline
\end{tabular}




\section{Appendix G: Universal Soil Loss Equation Data}

\begin{tabular}{ccccccccccc}
\hline Plot & Acres & $\mathbf{R}$ & $\mathbf{K}$ & $\mathbf{L}$ & $\mathbf{S}$ & LS & $\mathbf{C}$ & $\mathbf{P}$ & $\mathbf{A}$ & $\begin{array}{c}\text { Total } \\
\text { (tons ha }^{-1} \text { year }^{-1} \text { ) }\end{array}$ \\
\hline Low Use & 1 & 80 & 0.15 & 250 & 2 & 0.34 & 0.008 & 1 & 0.07 & 0.07 \\
Moderate Use & 1 & 80 & 0.15 & 250 & 1 & 0.22 & 0.08 & 1 & 0.5 & 0.5 \\
High Use-Edge & 1 & 80 & 0.14 & 250 & 1 & 0.22 & 0.08 & 1 & 0.4 & 0.4 \\
High Use-Center & 1 & 80 & 0.14 & 250 & 1 & 0.22 & 0.38 & 1 & 2.0 & 2.0 \\
\hline
\end{tabular}




\section{CERL Distribution}

Chief of Engineers

ATTN: CEHEC-IM-LH (2)

ATTN: HECSA Mailroom (2)

ATTN: CECC-R

ATTN: CERD-L

ATTN: CERD-M

Air Force Institute of Technology (3)

Wright-Patterson AFB, OH 45433-7765

US Air Force Academy 30840 (2)

ATTN: $510 \mathrm{CES} / \mathrm{CEVP}$

AF/ILEVP, Washington, DC 20330-1260

Defense Tech Info Center 22304

ATTN: DTIC-O (2) 
Public reporting burden for this collection of information is estimated to average 1 hour per response, including the time for reviewing instructions, searching existing data sources, gathering and maintaining the data needed, and completing and reviewing the collection of information. Send comments regarding this burden estimate or any other aspect of this collection of Information, including suggestions for reducing this burden, to Washington Headquarters Services, Directorate for information Operations and Reports, 1215 Jefferson Davis Highway, Suite 1204, Arlington, VA 22202-4302, and to the Office of Management and Budget, Paperwork Reduction Project (0704-0188), Washington, DC 20503.

\begin{tabular}{|l|l|c} 
1. AGENCY USE ONLY (Leave Blank) & $\begin{array}{c}\text { 2. REPORT DATE } \\
\text { December } 1999\end{array}$ & $\begin{array}{c}\text { 3. REPORT TYPE AND DATES COVERED } \\
\text { Final }\end{array}$ \\
\hline
\end{tabular}

4. TITLE AND SUBTITLE

Foot Traffic Effects on Grassland Soil Properties at the U.S. Air Force Academy, Colorado

6. AUTHOR(S)

R.C.A. Whitecotton, Mark B. David, Robert G. Darmody, and David L. Price

7. PERFORMING ORGANIZATION NAME(S) AND ADDRESS(ES)

U.S. Army Construction Engineering Research Laboratory (CERL)

P.O. Box 9005

Champaign, IL 61826-9005

8. PEFORMING ORGANIZATION REPORT NUMBER

TM 99/98
9. SPONSORING / MONITORING AGENCY NAME(S) AND ADDRESS(ES)

Assistant Chief of Staff (Installation Management)

ATTN: DAIM-ED-N

Directorate of Environmental Programs

600 Army Pentagon

Washington, DC 20310-0608

9. SUPPLEMENTARY NOTES

Copies are available from the National Technical Information Service, 5385 Port Royal Road, Springfield, VA 22161

12a. DISTRIBUTION / AVAILABILITY STATEMENT

Approved for public release; distribution is unlimited. AGENCY REPORT NUMBER
62720

A896

EN-TK7/EN-TM8

13. ABSTRACT (Maximum 200 words)

Soils and vegetation are subjected to stress and disturbance under human foot traffic. This study was conducted to determine whether training at the U.S. Air Force Academy adversely impacted soils and vegetation. In the summer of 1998, the effects of training on bulk density, infiltration, soil water holding capacity, soil total $\mathrm{C}$ and $\mathrm{N}$ con-centrations, soil C:N ratio, total aboveground biomass, and litter layer were comparatively studied at the Academy's Jack's Valley Training Area.

In May-June 1998 after 2 years of intensive training use, mean bulk densities of the top $6 \mathrm{~cm}$ of soil in the high use site (1.37 $\mathrm{g} \mathrm{cm}-3)$ and moderate use site $(1.30 \mathrm{~g} \mathrm{~cm}-3)$ were significantly different from bulk density of the reference site $(1.04 \mathrm{~g} \mathrm{~cm}-$ 3). Descriptive comparisons of the total aboveground biomass and litter showed a 68 percent decrease in total aboveground biomass and 91 percent decrease in litter when the high use site was compared to the low use site. Therefore, training use appears to adversely affect bulk density, infiltration, total aboveground biomass, and litter. Without restoration, previous research indicates that sites with increased bulk densities, decreased infiltration, and decreased total aboveground biomass and litter would be subject to increased soil erosion.

\begin{tabular}{|c|c|c|}
\hline \multicolumn{3}{|l|}{ 14. SUBJECT TERMS } \\
\hline \multicolumn{2}{|l|}{ military training } & \\
\hline \multicolumn{2}{|c|}{ U.S. Air Force Academy (USAFA) } & \\
\hline \multicolumn{3}{|c|}{ Ecological Dynamic Simulation (EDYS) model } \\
\hline $\begin{array}{l}\text { 17. SECURITY CLASSIFICATION } \\
\text { OF REPORT }\end{array}$ & $\begin{array}{l}\text { 18. SECURITY CLASSIFICATION } \\
\text { OF THIS PAGE }\end{array}$ & $\begin{array}{l}\text { 19. SECURITY CLASSIFICATION } \\
\text { OF ASTRACT }\end{array}$ \\
\hline Unclassified & Unclassified & Unclassified \\
\hline
\end{tabular}

\begin{tabular}{|l|l|}
\hline & $\begin{array}{l}\text { 15. NUMBER OF PAGES } \\
64\end{array}$ \\
\cline { 2 - 3 } & $\begin{array}{l}\text { 16. PRICE CODE } \\
\text { 20. LIMITATION OF } \\
\text { ABSTRACT } \\
\text { SAR }\end{array}$ \\
\hline
\end{tabular}

